Universidade de Brasília

Faculdade de Direito

Curso de Graduação em Direito

Monografia final de curso

Graduando: Pedro Luiz Tiziotti

Matrícula: 06/23750

\title{
Juízes Convocados nos Tribunais: Ponderação entre os \\ Princípios do Juiz Natural e da Razoável Duração do \\ Processo
}

\begin{abstract}
Monografia final de curso, requisito para graduação em Direito pela Universidade de Brasília, elaborada sob orientação do Professor Doutor, pela Universidade de São Paulo, Mohamad Ale Hasan Mahmoud, durante o primeiro semestre letivo de 2011.
\end{abstract}




\section{Sumário}

Agradecimentos

Introdução

1. Princípio

1.1. Definição de princípio

1.2. Definição de garantia

1.3. Definição de princípio-garantia

1.4. Terminologia adotada para o juiz natural e a razoável duração do processo

2. Princípio do juiz natural

2.1. Construção histórica do princípio

2.2. Princípio do juiz natural nas anteriores Constituições brasileiras

2.3. Definição do princípio do juiz natural

2.4. Previsão e significado do princípio no ordenamento jurídico pátrio

3. Correlação com outros princípios processuais

3.1. Princípio do devido processo legal

3.2. Princípio da imparcialidade do juiz

3.3. Princípio da legalidade

3.4. Princípio do duplo grau de jurisdição

3.5. Princípio da razoável duração do processo

4. Escorço histórico-jurisprudencial da eventual infringência ao juiz natural em virtude da convocação de juízes para atuar nos tribunais

4.1. Juízes convocados nos Estados em que havia tribunal de alçada

4.2. Maioria de convocados nos órgãos colegiados dos tribunais

4.3. Emenda Constitucional $n^{\circ}$ 45/2004 e câmaras extraordinárias

4.4. Resolução $n^{\circ} 72$ do Conselho Nacional de Justiça

4.5. Recente tratamento da matéria pelo Supremo Tribunal Federal

5. Juízes convocados e os princípios do juiz natural e da razoável duração do processo

5.1. Juízes convocados nos Estados em que havia tribunal de alçada

5.2. Câmaras extraordinárias e turmas suplementares

5.2.1. Câmaras extraordinárias no TJSP

5.2.2. Turmas suplementares no TRF da Primeira Região

5.2.3. Questão hierárquica e exemplo do TJDFT

5.3. Maioria de convocados nos órgãos colegiados dos tribunais

Conclusão

Referências bibliográficas 


\section{Agradecimentos}

Antes de tudo, parafraseando Humberto Ávila, quero - e me faz bem - agradecer:

- Aos meus avós, Tina, Lena, Vadinho e Aroldo (em memória ao avô que não tive a oportunidade de conhecer, mas por quem guardo, igualmente, amor profundo), por significarem o princípio, pelo carinho incomensurável e pelos exemplos de integridade.

- Aos meus pais, Marisa e Silvio, pelo amor incondicional, pelo empenho com que se dedicam à minha formação pessoal, por me permitirem sonhar alto e me incentivarem a lutar, com afinco, pelos meus ideias.

- À minha amada irmã, Bia, pelo exemplo de vida e superação.

- À Mariana, companheira incrível e profunda inspiradora.

- Aos amigos-irmãos, que me acompanham e são por mim acompanhados de perto e com o maior carinho, Marcelo, Arthur, Marco, Felipe, Christian, Frederico e João.

- Ao time de amigos da UnB; Pedro Henrique, Andrews, Rafael, Adriano, Luis Otávio, Breno, Luiz Gustavo, Alexandre, Guilherme Arantes, Rodrigo, Eduardo, Guilherme Rodrigues e Antônio, companheiros dentro e fora de campo, que a faculdade compartilhada seja apenas o início da amizade eterna.

- Aos integrantes da banca, que não poderiam ser outros, dada a importância que têm para mim, pelos seres humanos e Professores admiráveis que são, os que mais me marcaram e dos quais tentarei estar sempre perto, na busca incansável pelo aprendizado.

- Ao Professor, Orientador e amigo Mohamad Ale Hasan Mahmoud, elevado espírito, que muito me ensina de Direito e humanidade, pela dedicação, pelo carinho e brilho com que me orientou neste trabalho.

- Ao Professor e amigo Jorge Amaury Maia Nunes, por mérito elegido, à unanimidade, paraninfo da turma, pois carinhosamente nos acolheu e - muito mais do que nos ensinar - nos inspira a seguirmos o caminho da retidão, do estudo e do profissionalismo. Sou grato, também, pelas gentis recepções, estimadas contribuições e por nutrir em mim o gosto pelo Direito Processual Civil.

- Ao Desembargador Luciano Moreira Vasconcelos, pelo carinho com que me levou ao Tribunal, aos 14, e me estimulou a seguir o caminho do Direito, a quem devo o incentivo a uma de minhas maiores paixões. Agradeço, também, pelas inestimáveis contribuições.

- Ao Professor Rafael Santos de Barros, que tem gentilmente mantido contato comigo a respeito da monografia e do futuro profissional.

- À Professora e amiga Thaís Aroca Datcho Lacava, pela habitual delicadeza com que compartilhou comigo o trabalho com o qual obteve o título de Mestre.

- À Eliana, a quem tanto devo.

Saibam que, por serem muitos os destinatários dos meus agradecimentos, isso não os diminui em nada. Sou grato a todos; e muito 


\section{Introdução}

O Poder Judiciário tem como função precípua o exercício da jurisdição, que objetiva promover a pacificação social ${ }^{1}$. Para tanto, é imprescindível a presteza no dizer o direito, pois:

(...) a decisão tardia, assim como a mera ausência de decisão, não consegue atingir o fim da pacificação social almejado pelo Estado por meio do processo $^{2}$.

Ocorre que os Tribunais estão assoberbados de processos $^{3}$, de modo que se faz necessário refletir sobre meios de promover celeridade aos julgamentos, prestando, assim, homenagem ao princípio da razoável duração do processo, que após a Emenda Constitucional no 45/2004, foi expressamente previsto na Constituição Federal de $1988^{4}$.

Nesse contexto, a realização de mutirões de julgamento em primeira instância e a convocação de magistrados para atuar nos órgãos colegiados de tribunais tem sido cada vez mais comum.

Embora reconheçam o louvável desígnio almejado por meio dessas soluções, doutrina e jurisprudência manifestam a necessidade de observância do princípio do juiz natural na designação e convocação de magistrados ${ }^{5}$.

Este trabalho tem como finalidade predominante examinar o princípio do juiz natural e sua incidência sobre a disciplina dos órgãos colegiados de tribunais em que atuem juízes convocados. Mais especificamente, objetiva avaliar a eventual violação desse princípio (e em quais hipóteses isso ocorreria), em razão do julgamento de processos por câmaras ou turmas em que há convocados.

\footnotetext{
${ }^{1}$ Consoante ARAÚJO CINTRA; GRINOVER; DINAMARCO (2007, p. 31).

2 TUCCI apud LACAVA (2009, p. 45).

${ }^{3}$ Conforme assentou o Ministro Ricardo Lewandowski: “(...) os tribunais hoje estão espremidos, de um lado, pela chamada explosão de litigiosidade a que se referia o sociólogo português Boaventura de Sousa Santos, de outro lado, pelo CNJ que exige meta de produção e, de outro lado, pelos recursos que são escassos, humanos e materiais”. RE 597.133/RS, Relator Ministro Ricardo Lewandowski, Tribunal Pleno, julgado em 17.11.2010 e publicado no DJe de 6.4.2001.

${ }^{4}$ Art. $5^{\circ}$ Todos são iguais perante a lei, sem distinção de qualquer natureza, garantindo-se aos brasileiros e aos estrangeiros residentes no País a inviolabilidade do direito à vida, à liberdade, à igualdade, à segurança e à propriedade, nos termos seguintes: (...) LXXVIII a todos, no âmbito judicial e administrativo, são assegurados a razoável duração do processo e os meios que garantam a celeridade de sua tramitação.

${ }^{5}$ Os termos designação e convocação são empregados, correntemente, como sinônimos.
} 
A importância do tema decorre do fato de que ele diz respeito "não somente ao Direito Constitucional, como também ao Direito Processual"6. Nesse ponto, cumpre destacar:

É possível afirmar, sem temor de ser desmentido, que o fato mais relevante da ciência processual contemporânea seja constituído de uma decisiva tomada de consciência da sua dimensão constitucional ${ }^{7}$.

Mais precisamente, a matéria pertence à seara do Direito Constitucional Processual. Conforme ensina Nelson Nery Júnior:

(...) é comum dizer-se didaticamente que existe um Direito Constitucional Processual, para significar o conjunto das normas de Direito Processual que se encontra na Constituição Federal ao lado de um Direito Processual Constitucional, que seria a reunião dos princípios para o fim de regular a denominada jurisdição constitucional. Não se trata, portanto, de ramos novos do direito processual ${ }^{8}$.

O juiz natural, além de constituir princípio jurídico, engloba garantias dos cidadãos que são próprias do Estado Democrático de Direito, no qual é impositiva a observância, em especial pelo Estado, das regras do jogo (rules of the game) ${ }^{9}$. Conforme assentou Luiz Flávio Gomes:

Uma das mais salientes garantias do cidadão no atual Estado Democrático de Direito apóia-se no princípio do juiz natural ${ }^{10}$.

Em decorrência de sua vital importância, esse princípio, cujas origens remontam à Magna Carta inglesa de $1215^{11}$, “encontrou abrigo em quase todos os textos constitucionais e internacionais modernos" $"$.

Para atingir a finalidade almejada neste estudo, no primeiro capítulo serão analisados os conceitos de princípio e garantia, definindo-se, em seguida, o enquadramento do juiz natural como categoria normativa.

\footnotetext{
${ }^{6}$ SCHWAB (1987, p. 37).

7 TAORMINA (1972, p. 7), tradução própria. No original: "Può affermarsi, senza timore di essere smentiti, che il fatto più relevante della scienza processuale contemporanea sia costituito da una decisa presa di conscienza della sua dimensione costituzionale".

${ }^{8}$ NERY JÚNIOR (1992, p. 15).

${ }^{9}$ GOMES (1994, p. 418).

${ }^{10}$ Idem.

${ }^{11}$ GRINOVER (1984, p. 4).

12 GOMES (1994, p. 418).
} 
O segundo capítulo versará sobre o princípio do juiz natural. Primeiramente, far-se-á um breve relato da edificação histórica deste princípio, apresentando-se a sua disposição e seu significado nas distintas Constituições brasileiras. Após, serão abordadas possíveis definições para este princípio e o significado a ele atribuído pela Carta Política de 1988.

O terceiro capítulo estudará outros princípios que se ligam intimamente ao tema da monografia, em especial, os princípios da razoável duração do processo e do duplo grau de jurisdição.

O quarto capítulo relatará pesquisa jurisprudencial a respeito da eventual transgressão ao princípio em referência nos casos de órgãos colegiados formados com juízes convocados. Propôs-se a divisão das hipóteses em três: (i) juízes convocados nos Estados em que havia tribunal de alçada; (ii) maioria de convocados nos órgãos colegiados; e (iii) câmaras extraordinárias e turmas suplementares. Em seguida, serão abordados os objetivos da Resolução no 72 do Conselho Nacional de Justiça. Finalmente, serão descritos os casos em que o Supremo Tribunal Federal decidiu sobre o tema recentemente.

No quinto capítulo, por fim, defender-se-á o entendimento erigido ao longo deste estudo, em especial, em relação às três hipóteses propostas no capítulo anterior. 


\title{
1. Princípio
}

Pretende-se abordar neste capítulo a definição de princípio que dará embasamento ao estudo do juiz natural e da razoável duração do processo.

Entende-se ser imprescindível fazê-lo, visto que a doutrina constantemente refere-se aos princípios indistintamente, adotando como sinônimos termos como garantia e postulado, assim demonstrando “(...) a falta da desejável clareza conceitual na manipulação das espécies normativas" ${ }^{\prime 13}$.

Diante desta imprecisão terminológica surge a dúvida: será mesmo o juiz natural um princípio? Não será ele um postulado ou uma garantia?

Nesse ponto, Humberto Ávila é preciso ao afirmar que: “(...) o importante não é saber qual a denominação mais correta desse ou daquele princípio. $\mathrm{O}$ decisivo, mesmo, é saber qual é o modo mais seguro de garantir sua aplicação e sua efetividade" ${ }^{, 14}$.

No entanto, o rigor científico impõe a exigência de clareza conceitual $^{15}$, fazendo-se necessário atribuir denominações distintas a fenômenos diversos, a fim de tornar a comunicação entre o intérprete e seus destinatários a mais precisa possível.

Conforme observa o Professor gaúcho:

\begin{abstract}
A transformação dos textos normativos em normas jurídicas depende da construção de conteúdos de sentido pelo próprio intérprete. Esses conteúdos de sentido, em razão do dever de fundamentação, precisam ser compreendidos por aqueles que os manipulam, até mesmo como condição para que possam ser compreendidos pelos seus destinatários. É justamente por isso que cresce em importância a distinção entre categorias que o aplicador do direito utiliza. O uso desmesurado de categorias não só se contrapõe à exigência científica de clareza - sem a qual nenhuma Ciência digna desse nome pode ser erigida -, mas também compromete a clareza e a previsibilidade do Direito, elementos indispensáveis ao princípio do Estado Democrático de Direito ${ }^{16}$.
\end{abstract}

Com o objetivo de mais precisamente compreender os termos juiz natural e razoável duração do processo, buscar-se-á no tópico seguinte definir em qual

\footnotetext{
${ }_{13}$ ÁVILA (2011, p. 24).

${ }^{14}$ Idem.

15 No mesmo sentido, José Joaquim Gomes Canotilho ressalta que, na moderna constitucionalística, "aponta-se para a necessidade dogmática de uma clarificação tipológica da estrutura normativa". CANOTILHO (1991, p. 171-172).

${ }^{16}$ ÁVILA (2011, p. 24-25).
} 
categoria melhor se enquadram: na de princípios, postulados ou garantias. Para cumprir esse desiderato, inicialmente serão aventadas definições para cada uma dessas categorias.

\subsection{Definição de princípio}

Diversos autores ${ }^{17}$ propuseram definições para a categoria princípio $^{18}$ por meio da distinção das espécies do gênero norma: as regras e os princípios. A finalidade deste capítulo, no entanto, não é examinar a obra desses autores e as propostas por eles formuladas.

Para diferenciar as espécies do superconceito ${ }^{19}$ norma, adotar-se-á neste estudo a tipologia de princípios e regras de J. J. Gomes Canotilho, para quem a complexidade em distingui-los decorre da existência de variados critérios para fazê-lo.

De acordo com o Professor da Universidade de Coimbra, os princípios jurídicos - na qualidade de verdadeiras normas de conduta e não apenas em sua função argumentativa - distinguem-se das regras jurídicas com base, essencialmente, em quatro aspectos. Em primeiro lugar:

Os princípios são normas jurídicas impositivas de uma optimização, compatíveis com vários graus de concretização, consoante os condicionalismos fácticos e jurídicos; as regras são normas que prescrevem imperativamente uma exigência (impõem, permitem ou proíbem) que é ou não cumprida (nos termos de DWORKIN: applicable in all-or-nothing fashion); a convivência de regras é antinômica. Os princípios coexistem; as regras antinômicas excluem-se; ${ }^{20}$

Em segundo lugar, os princípios toleram o balanceamento de valores e interesses, de modo que, havendo colidência, poderão ser ponderados de acordo com

\footnotetext{
${ }^{17}$ Destacam-se na doutrina estrangeira, entre outros, os estudos de Josef Esser, Karl Larenz, ClausWilhelm Canaris, Ronald Dworkin e Robert Alexy. A esse respeito, ver o panorama da evolução da distinção entre princípios e regras em ÁVILA (2011, p. 35-40).

${ }^{18}$ Conforme Rogério Lauria Tucci, “o vocábulo princípio, etimologicamente, deriva do latino principium, principii - de princeps, principis (o primeiro), forma sincopada de primiceps, de primus (adjetivo superlativo de prae ou pro, por intermédio de pris, advérbio que significa antes, primeiramente, antigamente - o mesmo que prius) e de capere (captar, tomar, segurar, prender, conceber), cujo significado vulgar se mostra na origem, começo, início de qualquer coisa.” TUCCI (1986, p. 4).

${ }^{19}$ Expressão cunhada por CANOTILHO (1991, p. 172).

${ }^{20}$ CANOTILHO (1991, 173-174).
} 
seu peso no caso concreto ${ }^{21}$. As regras, por outro lado, devem ser cumpridas exatamente conforme sua prescrição, obedecendo à lógica do tudo ou nada (all-or-nothing).

Em terceiro lugar, em casos de conflitos de princípios, eles poderão ser harmonizados por meio de ponderação. De maneira diversa, não se comporta a validade simultânea de regras contraditórias, pois é inerente a esta espécie normativa a fixação de preceitos definitivos ${ }^{22}$.

Por fim, o Professor português conclui afirmando que os princípios promovem questões de validade e peso, já as regras suscitam apenas problemas de validade.

Além de distinguir as referidas espécies normativas, o autor divide os princípios jurídicos em quatro subespécies ${ }^{23}$ : (i) princípios jurídicos fundamentais; (ii) princípios políticos constitucionalmente conformadores; (iii) princípios constitucionais impositivos; e (iv) princípios-garantia.

Os princípios jurídicos fundamentais são aqueles "historicamente objectivados e progressivamente introduzidos na consciência jurídica"24. Esta categoria tem previsão constitucional, expressa ou tácita, e fundamenta a interpretação, o conhecimento e a aplicação do direito positivo. Conforme se depreende do conceito, exemplo desta espécie no ordenamento brasileiro é o princípio da dignidade da pessoa humana (artigo $1^{\circ}$, III, da Lei Maior).

Os princípios políticos constitucionalmente conformadores revelam, em síntese, os valores políticos fundamentais ao poder constituinte, que o inspiraram na elaboração da Constituição, sendo comum integrarem cláusulas pétreas. O princípio

\footnotetext{
${ }^{21} \mathrm{Na}$ mesma linha de ideias, Luís Roberto Barroso assevera com base em Alexy: "Em uma ordem democrática, os princípios freqüentemente entram em tensão dialética, apontando direções diversas. Por essa razão, sua aplicação deverá ocorrer mediante ponderação: à vista do caso concreto, o intérprete irá aferir o peso que cada princípio deverá desempenhar na hipótese, mediante concessões recíprocas, e preservando o máximo de cada um, na medida do possível. Sua aplicação, portanto, não será no esquema tudo ou nada, mas graduada à vista das circunstâncias representadas por outras normas ou por situações de fato. BARROSO (2009, p. 354).

${ }^{22}$ Em sentido contrário, ÁVILA sustenta: "Embora tentador e amplamente difundido, esse entendimento merece ser repensado. Isso porque em alguns casos as regras entram em conflito sem que percam sua validade, e a solução para o conflito depende de atribuição de peso maior a uma delas". ÁVILA (2011, p. 52-53).

${ }^{23}$ Propõe-se, a partir desse ponto, a utilização do termo espécie para as categorias propostas por CANOTILHO, gênero para os princípios e as regras e família para as normas, analogamente às classificações do ramo da biologia denominado taxonomia. A diferença é que na seara jurídica inexistiriam as categorias do reino, filo, classe e ordem.

${ }^{24}$ CANOTILHO (1991, p. 177).
} 
republicano é um exemplo desta espécie, previsto na Constituição Federal de 1988 (artigo $1^{\circ}$, caput).

Dentre os princípios constitucionais impositivos enquadram-se todos aqueles que, "no âmbito da constituição dirigente, impõem aos órgãos do Estado, sobretudo ao legislador, a realização de fins e de tarefas. São, portanto, princípios dinâmicos, prospectivamente orientados" ${ }^{\circ 2}$. Estes princípios destinam-se à definição e imposição de diretrizes. Exemplo desta espécie é o princípio da redução das desigualdades sociais e regionais (artigo $3^{\circ}$, III, da Carta Magna).

Para a definição dos princípios-garantia, reservou-se o tópico 1.3. Antes de abordar o assunto, tratar-se-á das garantias.

\subsection{Definição de garantia}

Assim como os princípios são comumente definidos a partir de seu cotejo com as regras, as garantias igualmente podem ser conceituadas por meio de sua comparação com os direitos.

Os direitos, segundo José Carlos Vieira de Andrade $^{26}$, têm como finalidade imediata proteger determinados bens das pessoas, como a vida, a liberdade, a honra. As garantias consideradas fundamentais objetivam proteger esses direitos de forma mediata, limitando, assim, o exercício do poder:

\footnotetext{
As garantias fundamentais asseguram ao indivíduo a possibilidade de exigir dos Poderes Públicos o respeito ao direito que instrumentalizam. Vários direitos previstos nos incisos do art. $5^{\circ}$ da Constituição se ajustam a esse conceito. Vejam-se, por exemplo, as normas ali consignadas de direitos processual $^{27}$.
}

Nesse contexto, nota-se que as garantias aproximam-se dos princípios. Daí advém a quarta espécie de princípios proposta por Canotilho, os princípiosgarantias.

\footnotetext{
${ }^{25}$ CANOTILHO (1991, p. 179).

${ }^{26}$ VIEIRA DE ANDRADE apud MENDES; COELHO; e GONET BRANCO (2007, p. 258).

${ }^{27}$ MENDES; COELHO; e GONET BRANCO (2007, p. 258).
} 


\subsection{Definição de princípio-garantia}

Consoante a tipologia de Canotilho, há determinados princípios que:

(...) visam instituir directa e imediatamente uma garantia aos cidadãos. Élhes atribuída uma densidade de autêntica norma jurídica e uma força determinante, positiva e negativa ${ }^{28}$.

Para esses princípios o autor designou a categoria de princípiosgarantia, aos quais está "o legislador estreitamente vinculado em sua aplicação"29, sugerindo como exemplos os seguintes: nulllum crimen sine lege, nulla poena sine lege, non bis is idem, in dubio pro reo e, inclusive, juiz natural.

Ante o exposto, percebe-se que a indefinição da doutrina ao designar determinados cânones jurídicos ora de princípio, ora de garantia, decorre do fato de que certos princípios manifestam, em seu âmago, justamente garantias dos cidadãos.

Ressalva-se, desde já, que durante a pesquisa acerca do princípio do juiz natural não se deparou com qualquer fundamentação para a indefinição terminológica, razão pela qual se entende ser fundamental fazê-lo aqui, em atendimento ao ideal de clareza científica, sem a qual, vale repisar, "nenhuma Ciência digna desse nome pode ser erigida (...), ${ }^{, 30}$ :

Não se trata, pois, de uma distinção meramente terminológica, mas de uma exigência de clareza conceitual: quando existem várias espécies de exames no plano concreto, é aconselhável que elas também sejam qualificadas de modo distinto ${ }^{31}$.

\subsection{Terminologia adotada para o juiz natural e a razoável duração do processo}

Segundo abordado, os princípios-garantia constituem princípios ambivalentes, visto que funcionam simultaneamente como princípio interpretativo do ordenamento jurídico e como garantia dos cidadãos a ser rigorosamente observada não só pelo legislador, mas também pelo intérprete da norma.

\footnotetext{
${ }^{28}$ CANOTILHO (1991, p. 179).

${ }^{29}$ GRAU apud CANOTILHO (1991, p. 179).

${ }^{30}$ ÁVILA (2011, p. 25).

${ }^{31}$ HUSTER apud ÁVILA (2011, p. 25).
} 
Por esse motivo, entende-se ser justificável o emprego de ambos os termos (princípio e garantia), desde que fundamentadamente, para designar tal categoria.

Conforme será visto nos dois capítulos seguintes, o juiz natural e a razoável duração do processo enquadram-se perfeitamente no conceito de princípiogarantia, motivo pelo qual, neste estudo, os dois termos serão utilizados para designálos, até como forma de evitar a repetição excessiva de expressões.

Também será empregado o vocábulo cânone para mencionar os dois citados princípios-garantia, levando em conta que o léxico define o termo assim: “norma, princípio geral do qual se inferem regras particulares"32.

Por outro lado, não se aplicará o termo postulado ${ }^{33}$ para denominá-los, tendo em vista que Humberto Ávila propõe a diferenciação entre princípios e postulados, considerando estes metanormas, normas de segundo grau:

\begin{abstract}
Os postulados funcionam diferentemente dos princípios e das regras. A uma, porque não se situam no mesmo nível: os princípios e as regras são normas objeto da aplicação; os postulados são normas que orientam a aplicação de outras. A duas, porque não possuem os mesmos destinatários: os princípios e as regras são primariamente dirigidos ao Poder Público e aos contribuintes; os postulados são frontalmente dirigidos ao intérprete e aplicador do Direito. A três, porque não se relacionam da mesma forma com outras normas: os princípios e as regras, até porque se situam no mesmo nível do objeto, implicam-se reciprocamente, quer modo preliminarmente complementar (princípios), quer de modo preliminarmente decisivo (regras); os postulados, justamente porque se situam num metanível, orientam a aplicação dos princípios e das regras sem conflituosidade necessária com outras normas ${ }^{34}$.
\end{abstract}

Por fim, não se utilizará o vocábulo direito para referência ao juiz natural e à razoável duração do processo, pois por meio deles não se protegem bens das pessoas, mas, em verdade, asseguram-se garantias em favor delas.

\footnotetext{
${ }^{32}$ HOUAISS (2001, p. 601).

${ }^{33}$ Termo empregado como sinônimo de princípio por diversos autores. A título de exemplo, veja-se: “(...) o postulado do Juiz Natural primeiramente desenvolve-se no ordenamento anglo-saxão e após desdobrouse no constitucionalismo francês e norte-americano, tendo chegado ao Brasil ainda na época do império com seu duplo efeito e consolidou-se numa garantia atualmente presente em quase todos os ordenamentos jurídicos dos países democráticos (...)”. SPAGNOLO (2003, p. 151).

${ }_{34}$ ÁVILA (2011, p. 134).
} 


\section{Princípio do juiz natural}

\subsection{Construção histórica do princípio}

Com o objetivo de compreender o hodierno significado do juiz natural, cumpre inicialmente relatar o desenvolvimento histórico do princípio e a forma como foi gradativamente alargando sua importância.

As origens dessa garantia remontam à Magna Carta inglesa, de 1215, que previa:

Art. 20. Nenhuma multa será lançada senão pelo juramento de homens honestos da vizinhança.

Art. 21. Condes e barões não serão multados senão pelos seus pares, e somente na conformidade com o grau de transgressão.

Art. 39. Nenhum homem livre será preso ou detido em prisão ou privado de suas terras, ou posto fora da lei ou banido ou de qualquer maneira molestado (sic); e não procederemos contra ele, nem o faremos vir a menos que por julgamento legítimo de seus pares e pela lei da terra ${ }^{35}$.

Àquela época, a função jurisdicional estatal ainda era incipiente. Vigia o sistema de jurisdição feudal, no qual competia aos proprietários da terra o papel de dizer o direito.

Aos poucos surgiram os juízes itinerantes, que funcionavam, no início, como meros inspetores reais e, posteriormente, passaram a atuar "como verdadeiros juízes, desempenhando a função jurisdicional estatal, concorrentemente com as Cortes Feudais" 36 .

A naturalidade do juiz ainda não significava proibição a juízos extraordinários $^{37}$, como era o exemplo dos juízes itinerantes. Constituía mera garantia de que ninguém seria julgado senão pelos seus pares ou pela lei da terra, conforme o disposto no artigo 39 da Carta Inglesa da época.

A vedação aos juízos extraordinários decorreu, inicialmente, da Petição de Direitos (Petition of Rights), de 1627, que dispôs:

\footnotetext{
${ }^{35}$ GRINOVER (1984, p. 4-5).

${ }^{36}$ GRINOVER (1984, p. 5).

${ }^{37}$ Também designados tribunais de exceção, de encomenda, extraordinários, ad hoc, ex post facto e ad personam.
} 
VIII - sob tal pretexto alguns súditos de Vossa Majestade foram mortos por certos comissários, quando e onde, se merecessem a morte pelas leis e estatutos da terra, pelas mesmas leis e estatutos poderiam ter sido julgados e por nenhuma outra deveriam ter sido julgados e executados ${ }^{38}$.

IX - (...) comissões essas, como quaisquer outras de igual natureza, são total e diretamente contrárias às ditas leis e costumes deste reino ${ }^{39}$.

Posteriormente, a Carta de Direitos (Bill of Rights), de 1689, também

determinou:

A comissão que instituiu a ex-corte dos comissários e cortes da mesma natureza é ilegal e nociva ${ }^{40}$.

Nota-se que, "na Inglaterra do Século XVII, o processo de estatização da justiça estava definitivamente consolidado" ${ }^{41}$, de modo a não mais se justificar a comissão, que havia adquirido dimensões extraordinárias, para aplicar a Lei Marcial a fatos preteritamente ocorridos.

Assim, o juiz natural incorporou o sentido de vedação aos juízos constituídos ex post facto, a partir da Petição de Direitos e da Carta de Direito inglesas.

Seguindo no processo de estruturação desse princípio, o Direito norteamericano foi o responsável por conferir-lhe status constitucional. Isso ocorreu com sua previsão na Declaração de Direitos da Virgínia, de 1776, e nas Constituições dos Estados independentes, de 1776 a 1784.

No constitucionalismo ianque, o princípio do juiz natural ligou-se à existência de juízos pré-determinados, de competência inderrogável. Desse modo, a competência - que constituía mero critério de organização judiciária - transfigurou-se em garantia de imparcialidade do juiz. Nesse passo, a Sexta Emenda à Constituição norte-americana de 1787, instituída em 1791, proclamou:

Em todos os processos penais o acusado terá direito a um julgamento rápido e público, por um júri imparcial do Estado e Distrito onde o crime houver sido cometido, distrito esse que será previamente estabelecido por $l \mathrm{ei}^{42}$.

\footnotetext{
${ }^{38}$ GRINOVER (1984, p. 6-7).

${ }^{39}$ GRINOVER (1984, p. 7).

${ }^{40}$ Idem.

${ }^{41}$ JACKSON apud GRINOVER (1984, p. 7).

42 Tradução própria.
} 
No ordenamento jurídico francês, a primeira menção ao juiz natural ocorreu no artigo 17, Título II, de Lei de 24.8.1790:

A ordem constitucional das jurisdições não pode ser perturbada, nem os jurisdicionados subtraídos de seus juízes naturais, por meio de qualquer comissão, nem mediante outras atribuições ou evocações, salvo nos casos determinados pela lei ${ }^{43}$.

No ano seguinte, a Constituição francesa previu:

Os cidadãos não podem ser subtraídos dos juízes que a lei lhes atribui, por nenhuma comissão, nem por outras atribuições e evocações, além das determinadas por $1 \mathrm{ei}^{44}$.

O princípio do juiz natural no Direito francês opunha-se aos institutos da comissão, da evocação, e da atribuição, intimamente ligados ao Estado Absolutista.

A respeito do primeiro instituto, Grinover explica:

Entendia-se por poder de comissão a instituição de órgãos jurisdicionais sucessivos ao crime, órgãos esses estranhos à organização judiciária, e conseqüentemente não previstos em lei. Ao poder de comissão corresponderia, na linguagem moderna, a instituição de juízos extraordinários, ex post facto ${ }^{45}$.

A evocação, diferentemente da comissão, significava atribuir competência a órgão integrante da organização judiciária, mas distinto do que houvera sido previsto como competente pela lei. Tal instituto corresponde ao que denominamos atualmente de derrogação da competência.

A atribuição, por sua vez, ocorria quando se conferia competência a determinado órgão para julgar matérias específicas, previamente à ocorrência do ato supostamente criminoso. Equivale ao que hodiernamente designamos juízos especiais.

Conforme se nota, o princípio do juiz natural adquiriu forma e força gradualmente, incorporando o significado de proibição aos institutos citados em períodos e ordenamentos jurídicos diversos. A proibição ao poder de comissão resulta dos textos ingleses do século XVII. A vedação ao instituto da evocação decorre do

\footnotetext{
${ }^{43}$ GRINOVER (1984, p. 10).

${ }^{44}$ Idem.

${ }^{45}$ Idem.
} 
constitucionalismo norte-americano. E o impedimento à atribuição é originário do Direito francês.

Posteriormente, o próprio ordenamento francês restringiu o princípio do juiz natural à proibição aos tribunais de exceção. Na Constituição Francesa de 1848:

(...) o sistema francês satisfez-se com uma única garantia do princípio do juiz natural: o da instituição de tribunais extraordinários, ex post facto, não mais se detendo na proibição da derrogação da competência. E, assim, o princípio da naturalidade do juiz ligou-se exclusivamente àquela forma particular de infringência à pré-constituição do juiz, consubstanciada na instituição de juízos extraordinários ${ }^{46}$.

A vigente Constituição italiana de 1948, muito embora influenciada pelo constitucionalismo francês, não se contentou com a mera garantia de vedação aos juízos extraordinários. Consagrou o princípio em sua maior amplitude, assegurando uma tríplice garantia ${ }^{47}$.

A Carta Política desse país coibiu a evocação na parte relativa aos "Direitos e Deveres do cidadão" e os juízos extraordinários e especiais no título referente à "Magistratura". Os artigos relativos ao tema dispõem, respectivamente:

Art. 25. Ninguém pode ser privado do juiz natural designado por lei.

(...)

Art. 102. A função jurisdicional é exercida pelos magistrados ordinários instituídos e regrados pelas normas sobre o ordenamento judicial. Não podem ser instituídos juízes extraordinários e juízes especiais. Podem somente instituir-se junto dos órgãos judiciais ordinários, sessões especializadas para determinados assuntos $(\ldots)^{48}$.

No ano de 1948, o princípio do juiz natural foi elevado ao âmbito do Direito Internacional, na Declaração Universal dos Direitos do Homem ${ }^{49}$, que prevê:

$\mathrm{X}$ - Toda pessoa tem direito, em plena igualdade, a uma audiência justa e pública por parte de um tribunal independente e imparcial, para decidir de seus direitos e deveres ou do fundamento de qualquer acusação criminal contra ela.

\footnotetext{
${ }^{46}$ TAORMINA apud GRINOVER (1984, p. 11-12).

${ }^{47}$ Expressão utilizada por GRINOVER para designar a proibição à comissão, evocação e atribuição.

${ }^{48}$ Constituição italiana traduzida para o português. Disponível em: http://www.provincia.milano.it/export/sites/default/diritticittadini/documenti/Portoghese.pdf. Acesso em: 4.5.2011.

49 Adotada e proclamada pela Resolução 217 A (III) da Assembleia Geral das Nações Unidas, em 10.12.1948, e assinada pelo Brasil na mesma data.
} 
Nessa seara, o Pacto Internacional dos Direitos Civis e Políticos ${ }^{50}$ também consagrou o princípio, dispondo:

Artigo 14 - 1 (...) Todas as pessoas têm direito a que sua causa seja ouvida equitativa e publicamente por um tribunal competente, independente e imparcial, estabelecido pela lei, que decidirá quer do bem fundado de qualquer acusação em matéria penal dirigida contra elas, quer das contestações sobre os seus direitos e obrigações de caráter civil.

A Convenção Americana sobre Direitos Humanos (Pacto de São José da Costa Rica) ${ }^{51}$ estabeleceu:

Artigo $8^{\circ}-1$. Toda pessoa tem direito a ser ouvida, com as devidas garantias e dentro de um prazo razoável, por um juiz ou tribunal competente, independente e imparcial, estabelecido anteriormente por lei, na apuração de qualquer acusação penal formulada contra ela, ou para que se determinem seus direitos ou obrigações de natureza civil, trabalhista, fiscal ou de qualquer outra natureza.

Finda a apresentação da evolução histórica do princípio do juiz natural, observa-se que o seu conteúdo foi paulatinamente adquirindo vigor - e, até mesmo, perdendo em determinados períodos. O mesmo aconteceu no Brasil, país em que a garantia da naturalidade do juízo é prevista constitucionalmente há muito.

\subsection{Princípio do juiz natural nas anteriores Constituições brasileiras}

O princípio do juiz natural tem previsão constitucional no ordenamento jurídico pátrio desde a primeira Carta Magna brasileira, a Constituição do Império de 1824.

Esse princípio foi recepcionado no Brasil com dúplice aspecto. Coibia os institutos da comissão e da evocação. Não se contrapunha, entretanto, ao instituto da atribuição, mas vedava o foro privilegiado. A Constituição Imperial dispôs:

XI. Ninguem será sentenciado, senão pela Autoridade competente, por virtude de Lei anterior, e na fórma por ella prescripta ${ }^{52}$.

\footnotetext{
50 Adotado pela Resolução 2.200-A (XXI) da Assembleia Geral das Nações Unidas, em 16.12.1966, ratificado pelo Brasil em 24.1.1992 e promulgada pelo Decreto ${ }^{\circ}$ 592, de 6.7.1992.

${ }^{51}$ Adotada em 22.11.1969, ratificada pelo Brasil em 25.9.1992 e promulgada pelo Decreto $\mathrm{n}^{\circ}$ 678, de 6.11 .1992$.

${ }^{52}$ Artigo 179, inciso XI.
} 
XVII. À exceção das Causas que, por sua natureza pertencem a Juízos particulares, na conformidade das Leis, não haverá Foro privilegiado, nem Commissões especiaes nas Causas Civeis, ou crimes ${ }^{53}$.

Posteriormente, a Carta republicana de 1891 estabeleceu no mesmo sentido:

$\S 15$ - Ninguém será sentenciado senão pela autoridade competente, em virtude de lei anterior e na forma por ela regulada ${ }^{54}$.

$\S 23$ - À exceção das causas que, por sua natureza, pertencem a Juízos especiais, não haverá foro privilegiado ${ }^{55}$.

A Lei Maior de 1934 previu:

25) Não haverá foro privilegiado nem Tribunais de exceção; admitem-se, porém, Juízos especiais em razão da natureza das causas ${ }^{56}$.

26) Ninguém será processado, nem sentenciado senão pela autoridade competente, em virtude de lei anterior ao fato, e na forma por ela prescrita ${ }^{57}$.

A Constituição de 1937 "não foi apenas um texto autoritário, como tantos outros que marcaram a nossa experiência constitucional. Foi, também, uma grande frustração institucional" ${ }^{, 58}$.

Inspirada em ideais nazi-fascitas, essa Constituição, além de omitir a garantia do juiz natural, acolheu expressamente o Tribunal de Segurança Nacional, que constituía tribunal de exceção. Conforme observou Grinover:

Já foi apontada a flagrante violação ao princípio do juiz natural configurada pela criação do Tribunal de Segurança, de 1935, cuja constitucionalidade, discutida pela Corte Suprema, foi resolvida, nas palavras de Pontes de Miranda, "um tanto à la legère"

No mesmo sentido, José Cirilo de Vargas afirmou:

Foi omissa a Carta de 37, uma vez que, após 1935, o famigerado "Tribunal de Segurança", símbolo de terror judicial e cuja constitucionalidade fora

\footnotetext{
${ }^{53}$ Artigo 179, inciso XVII.

${ }^{54}$ Artigo 72, § 15.

${ }^{55}$ Artigo 72, § 23 .

${ }^{56}$ Artigo 113, $\mathrm{n}^{\circ} 25$.

57 Artigo 113, no 26.

${ }^{58}$ MENDES; COELHO; GONET BRANCO (2007, p. 162).

${ }^{59}$ PONTES DE MIRANDA apud GRINOVER (1984, p. 22).
} 
posta em dúvida, trouxe problemas para o ditador. (...) Supunham ele [Francisco Campos] e outros figurões do regime, que tudo aquilo, então existente, era indispensável para combater o comunismo ${ }^{60}$.

Adiante o Professor mineiro concluiu:

Já tivemos, no país, casos de quebra do princípio: o exemplo maior foi o Tribunal criado por GETÚLIO [Tribunal de Segurança] para julgar seus adversários políticos ${ }^{61}$.

Na referida Carta previu-se:

17) os crimes que atentarem contra a existência, a segurança e a integridade do Estado, a guarda e o emprego da economia popular serão submetidos a processo e julgamento perante Tribunal especial, na forma que a lei instituir $^{62}$

Art. 172 - Os crimes cometidos contra a segurança do Estado e a estrutura das instituições serão sujeitos a justiça e processos especiais, que a lei prescreverát $^{63}$.

Tais dispositivos objetivaram dar legitimidade ao Tribunal de Segurança Nacional, criado em 1935, e que desde então tinha sua constitucionalidade discutida.

Findo o Estado Novo, encartou-se o princípio do juiz natural, mais uma vez, em sua tradicional dúplice garantia na Constituição de 1946:

$\S 26$ - Não haverá foro privilegiado nem Juízes e Tribunais de exceção ${ }^{64}$.

$\S 27$ - Ninguém será processado nem sentenciado senão pela autoridade competente e na forma de lei anterior ${ }^{65}$

A Lei Maior de 1967 descuidou da proibição à evocação. Por se tratar de uma Constituição autoritária, imposta sob a vigência da ditadura militar, limitou a naturalidade do juiz à vedação ao instituto da comissão, impedindo também o foro privilegiado:

\footnotetext{
${ }^{60}$ VARGAS (1992, p. 224).

${ }^{61}$ VARGAS (1992, p. 230).

${ }^{62}$ Constituição de 1937, artigo 122, no 17.

${ }^{63}$ Constituição de 1937, artigo 172.

${ }^{64}$ Constituição de 1946, artigo 141, § 26.

${ }^{65}$ Constituição de 1946, artigo 141, § 27.
} 
$\S 15$ - A lei assegurará aos acusados ampla defesa, com os recursos a ela inerentes. Não haverá foro privilegiado nem Tribunais de exceção ${ }^{66}$.

Antes de examinar o significado do juiz natural na Carta Política brasileira contemporânea, faz-se necessário sintetizar o conceito a ele atribuído hodiernamente.

\subsection{Definição do princípio do juiz natural}

Consoante se depreende da evolução histórica desse princípio inerente ao Direito Constitucional Processual ${ }^{67}$, sua acepção não é uniforme no tempo, nem tampouco nos ordenamentos jurídicos em que é previsto. O juiz natural tem sido amoldado de acordo com as peculiaridades do período e do país em que se insere.

Nessa linha de raciocínio, aduz o alemão Karl Heinz Schwab ${ }^{68}$ :

(...) o acolhimento dessas prescrições nas constituições ainda não significa que o princípio do juiz natural venha sendo entendido em todos os países na mesma dimensão. Pelo contrário, existem aqui consideráveis diferenças ${ }^{69}$.

Sobre a abrangência do princípio em seu país, ensina:

Na República Federal da Alemanha o princípio do juiz natural é compreendido em sentido abrangente. Em um número muito grande de decisões o Tribunal Constitucional Federal tem-se ocupado da interpretação do artigo 101, I, $2^{70}$, da Lei Fundamental ${ }^{71}$.

A forte carga valorativa do princípio no Direito germânico possivelmente decorre da traumática experiência do país em relação à Corte de Nuremberg. Esse Tribunal Militar Internacional julgou criminosos de guerra alemães nos anos de 1945 e 1946, o que constituiu uma das mais graves violações ao princípio

\footnotetext{
${ }^{66}$ Constituição de 1967 , artigo 150, § 15.

${ }^{67}$ Segundo NERY JÚNIOR (1992, p. 15).

${ }^{68}$ Ex-Professor Titular de Direito Processual Civil da Universidade de Erlangen-Nuremberg.

${ }^{69}$ SCHWAB (1987, p. 38).

${ }^{70}$ Prescreve o mencionado dispositivo: "ninguém pode ser subtraído do seu juiz natural”. SCHWAB (1987, p. 37).

${ }^{71} \operatorname{SCHWAB}(1987$, p. 38).
} 
do juiz natural (em especial, à proibição da comissão), resultando em julgamento imparcial que condenou doze pessoas à morte por enforcamento ${ }^{72}$.

Por esse motivo, os estudiosos do Direito Internacional designaram o fato histórico como uma justiça dos vencedores. A esse respeito, José Cirilo de Vargas manifestou:

\begin{abstract}
Não se admite a criação de órgãos judiciais especiais para o julgamento de certas causas, como aconteceu com o Tribunal Militar Internacional, criado especificamente para um arremedo de julgamento na histórica cidade de Nuremberg, tendo, como réus, os chefes nazistas que os Aliados conseguiram deter. Essa reunião, chamada de Tribunal, foi tão macabra, tão vergonhosa, tão ilegal e tão arbitrária que certos setores da opinião pública inglesa e norte-americana disseram abertamente que o procedimento dos Aliados não estava à altura das tradições democráticas e civilizadas do Ocidente ${ }^{73}$.
\end{abstract}

Do exposto, nota-se que o significado do princípio do juiz natural varia, em amplitude, nos diversos países em que foi consagrado. Do mesmo modo, sua denominação não é uniforme ${ }^{74}$. A despeito disso, há um núcleo substancial comum que o caracteriza em suas distintas concepções.

De acordo com o português Jorge de Figueiredo Dias, o princípio possui atualmente um tríplice significado, visto que se evidencia em três planos: o plano da fonte, o plano da competência e o plano temporal.

O primeiro determina que "só a lei pode instituir o juiz e fixar-lhe a competência"75.

O segundo plano objetiva garantir uma ordem taxativa de competência, de modo a excluir quaisquer formas de se fixar a jurisdição arbitrária ou discricionariamente.

Do plano da competência decorre a proibição de jurisdições extraordinárias, aquelas criadas ad hoc, com o desiderato de decidir determinado caso ou conjunto de casos, em desrespeito às regras gerais de competência.

\footnotetext{
${ }^{72}$ A crítica aqui é meramente à ausência de imparcialidade no julgamento. É óbvio que com o argumento não se pretende, de forma alguma, amenizar a responsabilidade dos nazistas pelas atrocidades cometidas no período anterior e concomitante à Segunda Guerra Mundial.

${ }^{73}$ VARGAS (1992, p. 224).

${ }^{74}$ No Direito alemão o princípio é denominado "juiz legal” (gesetzlicher Richter). Já no Direito espanhol a expressão é substituída por "juiz ordinário predeterminado pela lei" (Juez ordinário predeterminado por la Ley).

${ }^{75}$ DIAS (2009, p. 322).
} 
O plano temporal, por fim, indica a necessidade da fixação do juiz competente por meio de lei já vigente ao tempo em que foi praticado o fato supostamente criminoso.

O princípio do juiz natural diz respeito, assim, a uma garantia fundamental imanente à jurisdição nos Estados Democráticos de Direito. Nas palavras de Olivar Augusto Coneglian:

(...) a idéia do juiz natural encontra-se estritamente ligada à ideia e à existência do Estado Democrático de Direito, servindo contra eventual autoritarismo que pretenda se justificar por meio do Judiciário ${ }^{76}$.

Nesse sentido, Grinover define:

Mais do que um direito subjetivo da parte e para além do conteúdo individualista dos direitos processuais, o princípio do juiz natural é garantia própria da jurisdição, seu elemento essencial, sua qualificação substancial. Sem o juiz natural não há função jurisdicional possível ${ }^{77}$.

Para José Cretella Neto:

Juiz natural é aquele cujo poder de julgar é concedido pela Constituição ou por lei, contrapondo-se ao juiz (ou tribunal) indicado pelo Poder Executivo, sem base constitucional, como ocorre nas ditaduras, que criam os denominados tribunais de exceção ${ }^{78}$. (grifos no original).

\section{Conforme Guilherme de Souza Nucci:}

O juiz natural é aquele destinado, por critérios legais, antecipados e lógicos, sem artificialismo, a analisar determinada causa concreta, guardando equidistância das partes. Em verdade, cuida-se de um órgão judiciário criado para aguardar futuras demandas, figurando como guardião dos direitos e garantias individuais $^{79}$. (grifos no original).

\section{Américo Bedê Júnior e Gustavo Senna resumiram o princípio como:}

(...) o direito que toda pessoa - humana e jurídica - tem de saber, previamente, por qual juiz será julgada caso venha a ser submetida a um processo judicial. Daí se conclui que juiz natural é aquele constituído antes

\footnotetext{
${ }^{76}$ CONEGLIAN (2008, p. 159).

${ }^{77}$ GRINOVER (1984, p. 4).

${ }^{78}$ CRETELLA NETO (2006, p. 129).

${ }^{79}$ NUCCI (2010, p. 303).
} 
do fato a ser julgado, de acordo com a ordem taxativa de competência estabelecida em conformidade com a lei ${ }^{80}$.

Em síntese, são inúmeras as possíveis definições para o juiz natural. O que se conclui é que inerente aos conceitos haverá - conforme a maior ou menor abrangência do princípio em determinado ordenamento - a possibilidade ou não da comissão, evocação e atribuição.

Além disso, é imanente ao princípio a neutralidade e independência do juiz, a que Canotilho denominou: "garantia de justiça material" 81 . No mesmo sentido, Carlo Taormina leciona:

A doutrina felizmente tem observado que a naturalidade é uma qualificação substancial do juiz e isso quer dizer que ela se representa como atributo dele, de modo que a ausência da naturalidade prejudica o próprio conceito de juiz $^{82}$.

\title{
2.4. Previsão e significado do princípio no ordenamento jurídico pátrio
}

O juiz natural não abrange a vedação à atribuição no Brasil, de modo que não há atualmente qualquer óbice à criação de órgãos jurisdicionais especializados para determinadas matérias ou pessoas, desde que respeitados os referidos planos da fonte, da competência e do tempo:

\begin{abstract}
O sistema constitucional brasileiro jamais mostrou aversão à instituição de justiças especializadas, admitindo francamente o poder de atribuição. E com razão, porquanto o juiz natural, em sua dupla garantia, não se contrapõe a juízos especiais, orgânicos, pré-constituídos, integrantes do Poder Judiciário, em que o que ocorre é apenas uma prévia distribuição de competências, ora em razão das pessoas, ora em razão da matéria ${ }^{83}$.
\end{abstract}

Isso absolutamente não significa que o princípio seja entendido restritamente aqui. Pelo contrário, o direito brasileiro tradicionalmente interpreta o juiz natural em aspecto amplo. Nessa linha de argumentos, Rui Portanova aduz:

\footnotetext{
${ }^{80}$ BEDÊ JÚNIOR; SENNA (2008, p. 221).

${ }^{81}$ CANOTILHO apud TUCCI (2006, p. 81).

${ }^{82}$ TAORMINA (1972, p. 16), tradução própria. No original: "è stato felicemente osservato in dotrina che la naturalità è una qualificazione sostanziale del giudice e ciò vuol dire che la naturalità si rappresenta più che come attributo del giudice come l'in sé di esso di guisa che la sua assenza pregiudica lo stesso concetto di giudice.

${ }^{83}$ GRINOVER (1984, p. 21).
} 
O direito brasileiro tem sido pródigo em estender os limites da compreensão do juiz natural, dando-lhe cada vez mais importância. Podemos dizer que hoje o princípio do juiz natural tem aspectos que tocam tanto à jurisdição em geral (como segurança do cidadão) como ao processo em particular (como direito da parte e garantia do juiz) ${ }^{84}$.

Exemplo disso é a reivindicação, mormente por membros do Ministério Público, do princípio do promotor natural - previsto no artigo $5^{\circ}$, inciso LIII $^{85}$, da Constituição de 1998 - que surgiu:

(...) embrionariamente, das proposições doutrinárias pela mitigação do poder de designação do procurador geral da justiça, evoluindo para significar a necessidade de haver cargos específicos com atribuição própria a ser exercida pelo promotor de justiça, vedada a designação pura e simples, arbitrária, pelo procurador geral de justiça ${ }^{86}$.

Ao comentar o referido inciso constitucional, Hugo Nigro Mazzilli ${ }^{87}$

afirmou:

Realmente, este é o primeiro direito do acusado: não apenas o de ser julgado por um órgão independente do Estado, mas, até mesmo antes disso, o de receber a acusação independente, de um órgão do Estado escolhido previamente segundo critérios e atribuições legais, abolidos não só o procedimento de ofício e a acusação privada, como enfim e principalmente eliminada a figura do próprio acusador público de encomenda, escolhido pelo procurador-geral de justiça ${ }^{88}$. (grifos no original).

O princípio do promotor natural constitui garantia não só dos cidadãos, mas também dos próprios membros do Ministério Público. Conforme assentou o Ministro Celso de Mello:

(...) o postulado do Promotor Natural, que se revela imanente ao sistema constitucional brasileiro, repele, a partir da vedação de designações casuísticas efetuadas pela Chefia da Instituição, a figura do "acusador de exceção". Este princípio consagra uma garantia de ordem jurídica destinada tanto a proteger o membro do Ministério Público, na medida em que lhe assegura o exercício pleno e independente de seu ofício, quanto a tutelar a própria coletividade, a quem se reconhece o direito de ver atuando, em quaisquer causas, apenas o Promotor cuja intervenção se justifique a partir de critérios abstratos e predeterminados, estabelecidos em lei ${ }^{89}$.

\footnotetext{
${ }^{84}$ PORTANOVA (2001, p. 65).

${ }^{85}$ LIII - ninguém será processado nem sentenciado senão pela autoridade competente; (grifo aposto).

${ }^{86}$ NERY JÚNIOR (1992, p. 79).

${ }^{87}$ Conforme NERY JÚNIOR (1992, p. 79), Mazzilli foi o primeiro autor a abordar a ideia do promotor natural.

${ }^{88}$ MAZZILLI apud NERY JÚNIOR (1992, p. 81).

${ }^{89} \mathrm{HC} \mathrm{n}^{\mathrm{o}}$ 67.759/RJ, Relator Ministro Celso de Mello, Tribunal Pleno, julgado em 6.8.1992 e publicado no DJ de 1.7.1993.
} 
A Constituição brasileira de 1988 prevê o princípio do juiz natural, em seu artigo $5^{\circ}$, relativo aos direitos e garantias fundamentais do cidadão, de modo que o enquanto o inciso LIII proíbe a evocação, o inciso XXXVII veda a comissão:

LIII - ninguém será processado nem sentenciado senão pela autoridade competente; (grifo aposto).

XXXVII - não haverá juízo ou tribunal de exceção;

O juiz natural, portanto, é previsto em sua dúplice garantia, sendo interpretado extensivamente no Brasil. No plano da fonte, a competência dos órgãos jurisdicionais deve ser prevista na Constituição. Nesse sentido José Frederico Marques sustenta:

Em nosso sistema normativo, o que existe, de maneira concludente e clara, é o princípio de que ninguém pode ser subtraído de seu juiz constitucional. Somente se considera juiz natural ou autoridade competente, no direito brasileiro, o órgão judiciário cujo poder de julgar derive de fontes constitucionais $^{90}$.

Na mesma linha, Grinover assevera:

Acolhe, assim, o ordenamento brasileiro a concepção mais ampla do princípio do juiz natural, em sua feição moderna. Mais abrangente o princípio, no sistema jurídico brasileiro, porquanto no plano da fonte, só a Constituição - e não a lei - pode instituir o juízo e fixar sua competência ${ }^{91}$. (grifo no original).

No âmbito do Poder Judiciário, o princípio do juiz natural aplica-se a todos os magistrados e não apenas aos juízes de primeira instância:

Aduzem Celso Bastos e Ives Gandra que o juiz natural deve ser entendido não apenas como o juiz da sentença de primeiro grau, mas nele devem estar incluídos todos os juízes e tribunais chamados a intervir em determinado feito $^{92}$. (grifo no original).

Assim, o princípio deve ser observado pelos tribunais e, inclusive, por seus diversos órgãos fracionários e juízos:

\footnotetext{
${ }^{90}$ MARQUES (1979, p. 447).

${ }^{91}$ GRINOVER (1984, p. 39).

92 CRETELLA NETO (2006, p. 129).
} 
(...) o princípio do juiz natural exige não só uma disciplina legal da via judicial, da competência funcional, material e territorial do tribunal, mas também uma regra sobre qual dos órgãos judicantes (Câmara, Turma...) e qual juiz, em cada um desses órgãos individualmente considerado, deve exercer a sua atividade ${ }^{93}$.

Outro enfoque que demonstra a amplitude do princípio no Brasil refere-se à sua observância não apenas pelo Poder Judiciário, mas também pelos demais órgãos que exerçam jurisdição:

(...) também se enquadram dentro do conceito de juiz natural os casos de julgamentos feitos perante os outros poderes (...) como, por exemplo, o disposto no art. 52, I, da CF, em que o presidente da República é processado perante o Senado Federal. É de se considerar ainda que o artigo $5^{\circ}$, LIII, da CF não faz distinção sobre qual tipo de processo é assegurado pelo princípio ora mencionado, além de não apresentar nenhuma ressalva no sentido de que o processo deve ser entendido somente como o procedimento que corre perante o Poder Judiciário ${ }^{94}$.

Por fim, cumpre mencionar que, como forma de assegurar independência e imparcialidade aos juízes, características inerentes ao princípio do juiz natural, a Carta Política de 1988 prevê garantias aos magistrados de vitaliciedade, inamovibilidade e irredutibilidade de subsídio. Nesse sentido:

Entende-se que o juiz natural é aquele regular e legitimamente investido de poderes de jurisdição, dotado de todas as garantias inerentes ao exercício de ser cargo (vitaliciedade, inamovibilidade, irredutibilidade de vencimentos CF, art. 95, I, II, III), que decide segundo regras de competência fixadas com base em critérios gerais vigentes ao tempo do fato ${ }^{95}$.

Pelo quanto exposto, nota-se a vasta abrangência do princípio-garantia do juiz natural no ordenamento jurídico brasileiro.

\footnotetext{
${ }^{93}$ SCHWAB (1987, p. 38).

${ }^{94}$ CONEGLIAN (2008, p. 158).

${ }^{95}$ MENDES; COELHO; e GONET BRANCO (2007, p. 545).
} 


\title{
3. Correlação com outros princípios processuais
}

O princípio do juiz natural tem papel fundamental nos Estados que se pretendam de Direito ${ }^{96}$ e está umbilicalmente ligado a diversos princípios processuais, que potencializam sua importância, na qualidade de normas vinculantes e não de meros enunciados programáticos.

Esses princípios (devido processo legal, legalidade, imparcialidade do juiz, duplo grau de jurisdição e razoável duração do processo) têm em comum o fato de significarem garantia aos cidadãos da estrita observância das regras do jogo (rules of the game) pelo Poder Judiciário, no exercício da jurisdição ${ }^{97}$.

Nesse capítulo objetiva-se abordar a relação entre o juiz natural e os demais princípios que interessam ao tema dos juízes convocados, visto que:

(...) se o princípio ora em estudo [juiz natural] não estiver em consonância com os outros que serão agora destacados, ele não estará sendo respeitado, o que comprova, mais uma vez, que o sistema deve ser analisado como um todo, e que as interpretações devem procurar a integração dos mesmos ${ }^{98}$.

Sobre os princípios arraigados à função jurisdicional, vale ressaltar a lição de Eduardo Couture:

\begin{abstract}
Os princípios basilares, radicais, aqueles em tono de que se agrupa toda a experiência acerca da função e da incumbência do juiz, eu me permiti a reduzi-los a três ordens necessárias: a de independência, a de autoridade e a de responsabilidade. A de independência, para que suas decisões não sejam uma consequência da fome ou do medo; a de autoridade, para que suas decisões não sejam simples conselhos, divagações acadêmicas, que o Poder Executivo não possa desatender segundo seu capricho; e a de responsabilidade, para que a sentença não seja ímpeto da ambição, do orgulho ou da soberba, e sim da consciência vigilante do homem frente ao próprio destino ${ }^{99}$.
\end{abstract}

Enfatiza-se que há inúmeros princípios que se relacionam com o do juiz natural, de modo que esse capítulo almeja versar apenas sobre os que dele mais se aproximam e a forma como isso ocorre.

\footnotetext{
${ }^{96}$ Conforme CORDERO apud DIAS (1974, p. 2004), GOMES (1994, p. 418), LONGO (2003, p. 50), JARASS apud CRETELLA NETO (2006, p. 134), BEDÊ JUNIOR; SENNA (2008, p. 222), NUCCI (2010, p. 304), entre outros.

${ }^{97}$ Conforme GOMES (1994, p. 418).

${ }^{98}$ CONEGLIAN (2008, p. 161).

${ }^{99}$ COUTURE apud CRETELLA NETO (2006, p. 141).
} 
Tal abordagem se faz necessária com o intuito de estabelecer alicerces para uma posterior reflexão acerca da ponderação entre o princípio do juiz natural e o da razoável duração do processo. Assim, promover-se-á incursão crítica no seio do tema central deste trabalho.

\subsection{Princípio do devido processo legal}

O princípio do devido processo legal foi adotado expressamente no Direito brasileiro, pela primeira vez, com a Constituição Federal de $1988^{100}$, por influência do direito norte-americano. Esse princípio, ao robustecer as garantias processuais, tem por consequência avigorar, entre outros, também o princípio do juiz natural:

(...) a novidade, como se poderia imaginar, provocou profundas transformações no direito constitucional brasileiro, ainda que, em um primeiro momento, tenha servido apenas para reforçar as garantias processuais previstas na própria Constituição (e nas leis ordinárias) ${ }^{101}$.

Tamanha é a ligação entre os dois princípios (devido processo legal e juiz natural) que se afirma ser este cânone consequência lógica daquele:

Com efeito, como se percebe, a garantia de um julgamento justo, com respeito às garantias mínimas do processo, enfim, aos direitos fundamentais da pessoa humana, é essencial em um Estado que se diz "Democrático" e de "Direito". Daí porque configura tal princípio [juiz natural] um corolário lógico do devido processo legal $(. . .)^{102}$.

No mesmo sentido, Maria Thereza de Assim Moura aduz que "no direito brasileiro a garantia [do juiz natural] (...) integra a cláusula do devido processo legal" ${ }^{\prime 103}$.

A respeito da relação entre esses dois princípios:

Existem autores que até mesmo entendem que todos os princípios aqui mencionados (...), inclusive o objeto deste estudo [princípio do juiz natural], derivam de um único princípio mais amplo, o do devido processo legal. $\mathrm{O}$ efetivo processo legal deverá ser isento, seguindo o princípio do

\footnotetext{
${ }^{100}$ Conforme Adhemar Ferreira Maciel em "O Devido Processo Legal e a Constituição Brasileira de 1988" apud YOSHIKAWA (2007, p. 225).

${ }^{101}$ YOSHIKAWA (2007, p. 226).

102 BEDÊ JÚNIOR; SENNA (2008, p. 234).

${ }^{103}$ MOURA (2009, p. 224).
} 
contraditório, e as decisões ali tomadas deverão ser fundamentadas e públicas, lançadas por um juiz competente e previamente designado. Nessa linha, o que se deve ter em mente é que todos esses princípios se complementam como uma garantia própria da jurisdição ${ }^{104}$. (grifos apostos).

Por esses motivos, depreende-se que eventual infringência ao princípio do juiz natural acarretaria inevitável violação ao devido processo legal.

\subsection{Princípio da imparcialidade do juiz}

Assim como o princípio do devido processo legal, também da imparcialidade do juiz está intimamente ligado à naturalidade do juiz. Aquele, segundo Ferruccio Tommaseo $^{105}$ :

(...) não se trata de um valor abstrato, que diz respeito à moralidade do juiz, e sim, que o magistrado se encontre numa condição objetiva de imparcialidade. Portanto o legislador deve preocupar-se com a imparcialidade objetiva, isto é, em garantir que o juiz esteja em tal posição, relativamente à causa, que favoreça um juízo imparcial; não seria possível, de outra maneira, penetrar no íntimo do pensamento do juiz, de forma a assegurar uma imparcialidade subjetiva $^{106}$. (grifos no original).

O atributo da imparcialidade é indispensável à naturalidade do juiz, a ponto de um juiz parcial jamais poder ser considerado natural ${ }^{107}$ :

Absolutamente impossível se falar do princípio do juiz natural sem tratar do princípio da imparcialidade. Tal paridade revela-se pela simples condição de que o processo jurisdicional encontra-se visceralmente ligado à atuação do juiz no processo, podendo-se afirmar que a garantia da alheiabilidade consiste em pressuposto para sua existência ${ }^{108}$.

Nessa linha, Grinover sustenta, citando a doutrina italiana:

A imparcialidade do juiz, mais do que simples atributo da função jurisdicional, é vista hodiernamente como seu caráter essencial; e, em decorrência disso, a "imanência do juiz no processo", pela completa jurisdicionalização deste, leva à reelaboração do princípio do juiz natural, não mais identificado com um atributo do juiz, mas visto como pressuposto para

${ }^{104}$ CONEGLIAN (2008, p. 158).

105 Professor Titular da Università degli Studi di Verona.

106 TOMMASEO apud CRETELLA NETO (2006, p. 134).

${ }^{107}$ Em sentido contrário: “(...) apesar de existir o juiz natural, previamente indicado para a composição de conflitos, demanda-se o juiz imparcial, tendo em vista que, conforme a situação, pode-se encontrar um magistrado natural, mas parcial". NUCCI (2010, p. 305).

${ }^{108}$ LONGO (2003, p. 36-37). 
sua própria existência. Eis, assim, a naturalidade do juiz erigida em qualificação substancial, em núcleo essencial da função jurisdicional ${ }^{109}$.

Em verdade, não só a imparcialidade é condição sine qua non da naturalidade. É possível afirmar que os princípios do juiz natural e da imparcialidade do juiz são interdependentes, pois é com a garantia do juiz natural que:

(...) fica assegurada a imparcialidade do juiz, vista não como atributo do juiz, mas como pressuposto da própria existência da atividade jurisdicional. Com isso a garantia não é mais enfocada em face do conceito individualista de garantia da parte, mas como garantia da própria jurisdição ${ }^{110}$.

Com o intuito de assegurar imparcialidade e naturalidade do juiz, é necessário garantir, sobretudo, sua independência, pois esta, conforme os ensinamentos de Couture, é imprescindível "para que suas decisões não sejam consequência da fome ou do medo" $" 111$. No mesmo sentido:

(...) importante manifestação da imparcialidade diz respeito à ligação dessa com a independência, que visa a assegurar autonomia funcional do órgão judicante, imune a ordens e instruções hierárquicas, enquanto no exercício das atividades jurisdicionais ${ }^{112}$.

\subsection{Princípio da legalidade}

Consoante a lição de Figueiredo Dias acerca do juiz natural, um dos planos desse princípio é o da fonte, para o qual a ordem taxativa de competência dos ordenamentos jurídicos deve ser estabelecida em lei. Assim, faz-se evidente que a legalidade também é intrínseca à naturalidade do juiz.

Nas palavras de Piero Calamandrei "o juiz natural é a garantia que se apresenta como inseparável do sistema da legalidade" $" 113$.

É que a jurisdição - conforme já asseverava a doutrina italiana, no início do século passado -, para ser considerada legítima, deve ser:

a) legal, no sentido de que não se poderá derrogar a organização judiciária senão por força de uma lei; b) positiva e indeclinável,

\footnotetext{
${ }^{109}$ GRINOVER (1984, p. 3-4).

${ }^{110}$ FERNANDES (2007, p. 133).

${ }^{111}$ COUTURE apud CRETELLA NETO (2006, p. 141).

${ }^{112}$ LONGO (2004, p. 41).

${ }^{113}$ CALAMENDREI apud MARQUES (1977, p. 446).
} 
afirmando que ninguém pode se subtrair à jurisdição exceto nos casos previstos em lei; c) inalterável, no sentido de que uma vez que firmada pela lei, não possa modificar-se o juiz natural ${ }^{114}$.

Nessa linha de ideias, o Ministro Celso de Mello assentou:

(...) se revela da essencialidade inquestionável a função da lei, cujas prescrições - necessárias e insubstituíveis -, desde que fundadas em critérios gerais, abstratos, impessoais e apriorísticos, ajustam-se, em face da própria natureza do instrumento a que aderem, às exigências do postulado do juiz natural... Posta a questão nestes termos, é de ressaltar, com a doutrina, a absoluta imprescindibilidade da lei - e não de qualquer outra espécie normativa dotada de menor grau de positividade jurídica - para disciplinar, nas causas penais, o próprio processo de substituição (e de designação, acrescentamos) dos juízes $(. . .)^{115}$.

\subsection{Princípio do duplo grau de jurisdição}

O princípio do duplo grau de jurisdição não se relaciona intimamente com o do juiz natural, como acontece com os princípios acima abordados ${ }^{116}$. Não obstante isso, interessa à monografia, pois se alega que a violação deste - quando acarreta a nulidade de julgamentos de tribunais de segunda instância - teria por consequência violar, também, o princípio do duplo grau de jurisdição. Por esse motivo, impõe-se analisá-lo neste trabalho.

\section{Acerca do princípio, Chiovenda leciona:}

(...) duplo grau de jurisdição consiste em que toda causa, com exceção dos casos enumerados na lei, deve poder transitar pela plena cognição de dois tribunais sucessivamente; e esse duplo grau, na intenção do legislador, representa uma garantia para os cidadãos sob três aspectos:

a) na medida em que um reiterado julgamento torna, já por si, possível a correção de erros;

b) porque os dois julgamentos são confiados a juízes diversos;

c) uma vez que o segundo juiz se apresenta como mais autorizado que o primeiro $(\ldots)^{117}$.

\footnotetext{
${ }^{114}$ LUCCHINI apud LONGO (2003, p. 39).

115 Voto do Relator Ministro Celso de Mello no HC nº 69.601/SP, Primeira Turma, julgado em 24.11.1992 e publicado no DJ de 18.12.1992.

${ }^{116}$ Nas palavras de I’talo Fioravanti Sabo Mendes: “Analisadas essas idéias gerais acerca do princípio do juiz natural, pode-se então dizer que o duplo grau de jurisdição não se encontra incluído no âmbito do princípio do juiz natural" (2008, p. 281).

${ }^{117}$ CHIOVENDA apud MENDES (2008, p. 15).
} 
Nota-se que o princípio do duplo grau de jurisdição possui tríplice aspecto. Os dois primeiros citados por Chiovenda dizem respeito à segurança jurídica, pois, em tese, minimizam as chances de erros judiciais:

O duplo grau de jurisdição, por assegurar ao cidadão, pela via do recurso dirigido aos tribunais de segundo grau, a revisão das decisões proferidas pelos juízes em primeiro grau, tem sido histórica e constantemente analisado como uma garantia do ser humano contra a possibilidade da ocorrência de "erros judiciais"118.

Por fim, o terceiro aspecto do princípio do duplo grau de jurisdição está relacionado à análise da causa em segunda instância por juízes mais experientes em tese e, portanto, mais autorizados.

\subsection{Princípio da razoável duração do processo}

O princípio da razoável duração do processo tampouco tem relação direta com o juiz natural. Não obstante isso, o princípio é do maior interesse ao tema da convocação de magistrados, tendo em vista que as convocações, para substituição ou auxílio, têm por finalidade aumentar a produtividade do tribunal, evitando-se assim a lentidão na prestação jurisdicional, pois:

(...) a decisão tardia, assim como a mera ausência de decisão, não consegue atingir o fim da pacificação social almejado pelo Estado por meio do processo $^{119}$.

Nos termos cunhados por Rui Barbosa: “(...) justiça atrasada não é justiça, senão injustiça qualificada e manifesta" ${ }^{\text {"20. }}$.

Embora não tenha sido reconhecido expressamente pela original redação da Constituição Federal de 1988, afirma-se que o princípio da razoável duração do processo já integrava o sistema constitucional brasileiro, visto que foi consagrado em

\footnotetext{
${ }^{118}$ MENDES (2008, p. 1).

119 TUCCI apud LACAVA (2009, p. 45).

${ }^{120}$ BARBOSA (1999, p. 40).
} 
tratados internacionais dos quais a República Federativa do Brasil é parte ${ }^{121}$, o que se baseia no $\S 2^{\circ}$ do $\operatorname{artigo} 5^{\circ}$ da Carta Magna ${ }^{122}$.

Sobre a garantia da razoável duração do processo, Thaís Lacava aduz

que:

(...) já era corrente, na doutrina, a afirmação de que esta, embora não viesse expressa no texto constitucional, decorria naturalmente de outras garantias, principalmente a do devido processo legal e a do acesso à justiça. Para chegar a esta aproximação, a doutrina se baseava freqüentemente no exemplo norteamericano, que inclui a cláusula do speedy trial na cláusula do devido processo legal $^{123}$.

E, em seguida, assevera:

A própria determinação constitucional do $\S 2^{\circ}$ do $\operatorname{artigo} 5^{\circ}$ (...) permitia afirmar com segurança que a garantia do prazo razoável para a duração do processo integrava o sistema de garantias constitucionais mesmo sem uma previsão expressa $^{124}$.

Daí advém a importância desse princípio ao trabalho, visto que inerente à solução dos casos que envolvam alegação de infringência ao princípio do juiz natural na convocação de magistrados - supostamente haverá, ainda que de maneira implícita, um juízo de ponderação entre o princípio da razoável duração do processo e o do juiz natural.

Essa ponderação, no entanto, deve levar em conta que é indesejável suprimir garantias processuais dos cidadãos sob o pretexto de tornar a prestação judicial mais célere. E isso se torna ainda mais evidente quando se trata de garantias fundamentais, constitucionalmente previstas, como é o caso da naturalidade do juiz.

Consoante a lição de Canotilho:

A exigência de um processo sem dilações indevidas, ou seja, de uma proteção judicial em tempo adequado não significa necessariamente 'justiça acelerada'. A aceleração da protecção judicial que se traduza em diminuição

\footnotetext{
${ }^{121}$ Tais como a Declaração Americana dos Direitos e Deveres do Homem, que dispôs em seu artigo XVIII: "Toda pessoa pode recorrer aos tribunais para fazer respeitar os seus direitos. Deve poder contar, outrossim, com processo simples e breve, mediante o qual a justiça a proteja contra atos de autoridade que violem, em seu prejuízo, quaisquer dos direitos fundamentais consagrados constitucionalmente".

${ }^{122} \S 2^{\circ}$ - Os direitos e garantias expressos nesta Constituição não excluem outros decorrentes do regime e dos princípios por ela adotados, ou dos tratados internacionais em que a República Federativa do Brasil seja parte.

${ }^{123}$ LACAVA (2009, p. 49).

${ }^{124}$ LACAVA (2009, p. 50).
} 
de garantias processuais e materiais (prazos de recurso, supressão de instâncias) pode conduzir a uma justiça pronta, mas materialmente injusta ${ }^{125}$.

Entendimento semelhante é esposado por Hélio Tornaghi, para o qual a celeridade é almejada:

(...) mas sempre cuidando que não se mutilem as garantias, quer de observância do Direito objetivo, quer de respeito aos direitos subjetivos das partes ou de terceiros. O acerto da decisão prima sobre a sua presteza. É preciso que a ligeireza não se converta em leviandade, que a pressa não acarrete a irreflexão. O juiz deve buscar a rápida solução do litígio, mas tem que evitar o açodamento, o afogadilho, a sofreguidão. Deve ser destro, sem ser precipitado; pontual, sem imprudência. O juiz inconsiderado é ainda pior que o vagaroso. A observância rigorosa das formas e prazo legais é a melhor receita para conciliar a rapidez e a segurança ${ }^{126}$.

Destarte, nota-se que o desiderato de promover celeridade e presteza à prestação jurisdicional não pode justificar a violação de garantias processuais, em especial, a do juiz natural.

${ }^{125}$ CANOTILHO apud LACAVA (2009, p. 50).

${ }^{126}$ TORNAGHI apud LACAVA (2009, p. 51). 


\section{Escorço histórico-jurisprudencial da eventual infringência ao juiz natural em virtude da convocação de juízes para atuar nos tribunais}

\section{O Supremo Tribunal Federal e o Superior Tribunal de Justiça} debateram, já no início da década de 90, o tema referente à eventual violação do princípio do juiz natural em virtude da formação de órgãos colegiados de tribunais com juízes convocados em substituição ou auxílio a membros efetivos.

A partir de então, o assunto vem sendo enfrentado pelas cortes superiores pátrias, sob diversos aspectos, conforme relato a seguir.

\subsection{Juízes convocados nos Estados em que havia tribunal de alçada}

No começo da década de 90, discutia-se a possibilidade de convocação de juízes de direito da comarca da capital para comporem órgão colegiado de tribunais de justiça de Estados em que havia tribunal de alçada.

Sustentava-se que a convocação deveria recair sobre membro do tribunal de alçada, conforme o artigo 93 da Constituição Federal de 1988:

Art. 93. Lei complementar, de iniciativa do Supremo Tribunal Federal, disporá sobre o Estatuto da Magistratura, observados os seguintes princípios:

(...)

III - o acesso aos tribunais de segundo grau far-se-á por antiguidade e merecimento, alternadamente, apurados na última entrância ou, onde houver, no Tribunal de Alçada, quando se tratar de promoção para o Tribunal de Justiça, de acordo com o inciso II e a classe de origem; (grifos apostos)

A esse respeito, a LOMAN $^{127}$ - instituída sob a vigência da

Constituição Federal de 1969 - dispunha:

Art. 100. Na composição de qualquer Tribunal, um quinto dos lugares será preenchido por advogados, em efetivo exercício da profissão, e membros do Ministério Público, todos de notório merecimento e idoneidade moral, com dez anos, pelo menos, de prática forense.

(...)

$\S 3^{\circ}$ Nos Estados em que houver Tribunal de Alçada, constitui este, para efeito de acesso ao Tribunal de Justiça, a mais alta entrância da Magistratura estadual. (grifos apostos)

\footnotetext{
${ }^{127}$ Lei Orgânica da Magistratura Nacional - Lei Complementar nº 35/79.
} 
Art. 118. Em caso de vaga ou afastamento, por prazo superior a 30 (trinta) dias, de membro dos Tribunais Superiores, dos Tribunais Regionais, dos Tribunais de Justiça e dos Tribunais de Alçada, (vetado) poderão ser convocados Juízes, em substituição (vetado) escolhidos (vetado) por decisão da maioria absoluta do Tribunal respectivo, ou, se houver, de seu Órgão Especial: (Redação dada pela Lei Complementar $n^{\circ} 54$, de 22.12.1986)

$\S 1^{\circ}$ A convocação far-se-á mediante sorteio público dentre:

(...)

III - Os Juízes da Comarca da Capital para os Tribunais de Justiça dos Estados onde não houver Tribunal de Alçada e, onde houver, dentre os membros deste para os Tribunais de Justiça e dentre os Juízes da Comarca da sede do Tribunal de Alçada para o mesmo; (grifos apostos)

Em relação ao tema, destacaram-se no Pretório Excelso o julgamento dos Habeas Corpus n ${ }^{\circ} 68.210 / \mathrm{RS}^{128}$ e n ${ }^{\circ} 68.905 / \mathrm{SP}^{129}$.

No primeiro, discutiu-se a regularidade da atuação de juiz de direito de Porto Alegre, como relator, em câmara do Tribunal de Justiça do Rio Grande do Sul (TJRS). Na oportunidade, o juiz em referência substituía membro efetivo daquela corte.

O plenário do Supremo Tribunal Federal decidiu, em síntese, declarar a nulidade do acórdão de segunda instância, pois o artigo $118, \S 1^{\circ}$, III, da LOMAN em observância ao artigo 93, III, da Constituição Federal - determinava que a escolha de magistrado para atuar nos tribunais de justiça dos Estados, em regime de substituição, deveria recair sobre membro do tribunal de alçada, onde houvesse. Inexistindo, os convocáveis passariam a ser juízes da comarca da capital.

Assim, no Tribunal de Justiça do Rio Grande do Sul a clientela de convocação ${ }^{130}$ deveria incidir obrigatoriamente sobre membros do tribunal de alçada deste Estado.

O relator, Ministro Sepúlveda Pertence, asseverou em seu voto:

(...) não se compreende, com efeito, porque admitir a convocação, para substituição eventual no Tribunal de Justiça ou para ocupar-lhe provisoriamente as vagas, do juiz que, no escalonamento hierárquico da carreira, a ele não possa ter acesso definitivo.

O raciocínio permanece válido sob a nova Constituição, que absorveu, no art. 93, III, a regra do referido art. 100, § $3^{\circ}$, da Lei Orgânica.

\footnotetext{
${ }^{128}$ Relator Ministro Sepúlveda Pertence, Tribunal Pleno, julgamento iniciado em 12.9.1990 e findo em 18.12.1991, publicado no DJ de 21.8.1992.

${ }^{129}$ Relator Ministro Néri da Silveira, Segunda Turma, julgado em 10.12.1991 e publicado no DJ de 15.5.1992.

${ }^{130}$ Expressão empregada pelo relator, Ministro Sepúlveda Pertence.
} 
Tenho por manifesto, assim, que a presença, na Câmara, do ilustre magistrado de primeiro grau, maculou o julgamento.

Trata-se de nulidade absoluta, de seu turno, é inequívoco, seja porque o Juiz de Direito foi o relator do recurso, seja porque, em apelação criminal, tendo sido unânime a decisão desfavorável à defesa, todo voto há de reputar-se decisivo, porque obstruiu o caminho dos embargos infringentes.

Em seguida, aduziu:

(...) é tema, logo se vê, que diz com a organização de um poder do Estado e tem implicações com a garantia do juiz natural, que reclama, no início, o juiz legal: investido, ainda que provisoriamente, na forma da lei, não do regimento.

O ministro Celso de Mello, acompanhando o Relator, afirmou:

Entendo assistir razão ao eminente Relator, cujo voto (...) deixou claramente consignado que o procedimento de substituição de magistrados, disciplinado regimentalmente no âmbito do Egrégio Tribunal de Justiça do Estado do Rio Grande do Sul, importou em irrecusável lesão ao princípio do Juiz Natural. (grifo no original).

Acompanharam o Relator, além do Ministro Celso de Mello, os

Ministros Marco Aurélio, Néri da Silveira e Sydney Sanches. Vencido, o Ministro Carlos Velloso.

No segundo Habeas Corpus, agora no fracionário âmbito da Segunda Turma, os impetrantes objetivavam a declaração da nulidade de acórdão prolatado pelo Tribunal de Justiça do Estado de São Paulo. Sustentavam contrariar o artigo 118 da LOMAN o fato de o relator, bem como o revisor do recurso de apelação, integrarem o órgão julgador na condição de juízes de direito e não de desembargadores.

O Relator, Ministro Néri da Silveira, citou em seu voto trecho do voto vencido do Ministro Carlos Velloso no julgamento do comentado Habeas Corpus $\mathrm{n}^{\circ}$ 68.210/RS, sustentando ser inaplicável ao caso a obrigatoriedade de convocação de membro do tribunal de alçada para atuar no Tribunal bandeirante. Em seguida, resumiu:

Em suma, estou em que, com a promulgação da Constituição de 1988, compete aos Tribunais regular, no Regimento Interno, a forma de convocação para o exercício de substituição eventual de seus membros (CF/ 88, art. 96, I, “a”), não sendo impositivo na convocação, o critério inscrito no art. 93, III, da Lei Maior. 
O posicionamento firmado no julgamento do Habeas Corpus $\mathrm{n}^{\circ}$ 68.210/RS não prevaleceu neste caso, visto que o sistema de convocação dos juízes no Estado de São Paulo foi previsto com base na Lei Complementar Estadual no 646/1990. No Rio Grande do Sul, por outro lado, esse sistema foi previsto no regimento interno do Tribunal de Justiça do Estado.

No Superior Tribunal de Justiça, o assunto foi aventado no Recurso Especial $\mathrm{n}^{\mathrm{o}} 11.838 / \mathrm{RS}^{131}$, ao qual a Primeira Turma deu provimento por unanimidade. $\mathrm{O}$ acórdão restou assim ementado:

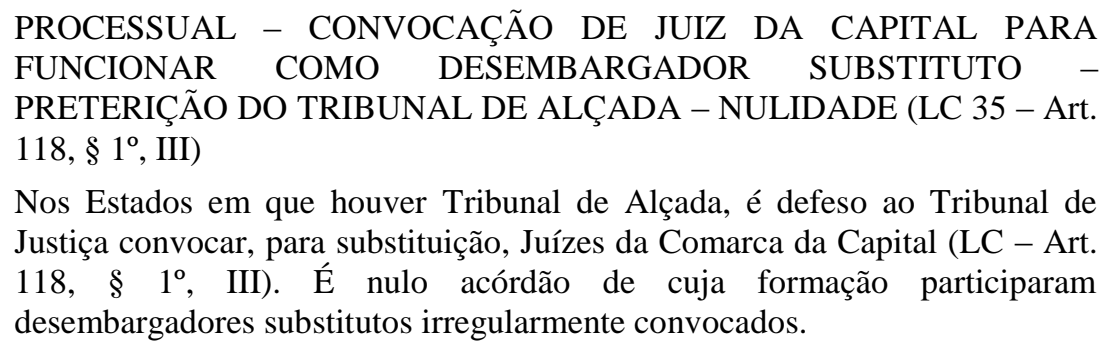

\subsection{Maioria de convocados nos órgãos colegiados dos Tribunais}

A violação ao princípio do juiz natural também já havia sido sustentada nas hipóteses em que o órgão colegiado estivesse composto majoritariamente por juízes convocados.

A Primeira Turma do Supremo Tribunal Federal deliberou sobre o tema em 1998, no Habeas Corpus $\mathrm{n}^{\mathrm{o}} 78.051 / \mathrm{PB}^{132}$, de relatoria do Ministro Sepúlveda Pertence. Na oportunidade, a Turma concedeu em parte a ordem. No que diz respeito ao tópico, o acórdão restou assim ementado:

3. Nulidade conseqüente da condenação em que a maioria absoluta do colegiado prolator do acórdão for composta por Juízes de Direito convocados para substituir Desembargadores ausentes por motivos diversos.

Já no ano 2000 a questão foi suscitada perante o Superior Tribunal de Justiça no Habeas Corpus n ${ }^{\circ} 9.405 / \mathrm{SP}^{133}$. Sustentavam os impetrantes, entre eles o ex-

\footnotetext{
${ }^{131}$ Relator Ministro Humberto Gomes de Barros, Primeira Turma, julgado em 31.3.1993 e publicado no DJ de 10.5.1993.

${ }^{132}$ Relator Ministro Sepúlveda Pertence, Tribunal Pleno, julgamento iniciado em 27.10.1998 e findo em 10.11.1998, publicado no DJ de 17.9.1999.

${ }^{133}$ Relator Ministro Hamilton Carvalhido, Relator para acórdão Ministro William Patterson, Sexta Turma, julgado em 11.4.2000 e publicado no DJ de 18.6.2001.
} 
Ministro da Justiça Márcio Thomaz Bastos, nulidade do acórdão de segunda instância, em razão da participação de dois juízes convocados no julgamento da apelação, que atuaram como relator e revisor.

O relator do mandamus, Ministro Hamilton Carvalhido, resumiu o imbróglio durante sessão da Sexta Turma do Superior Tribunal de Justiça:

\begin{abstract}
A jurisprudência do nosso Tribunal não está uniformizada no que diz respeito a esta matéria. Assim como o ilustre Advogado recolheu acórdão da lavra do Ministro Humberto Gomes de Barros, colhi outros precedentes, o último dos quais, do Eminente Ministro Waldemar Zveiter, no sentido contrário da tese aqui sustentada.
\end{abstract}

Ao fim do julgamento, a Turma concedeu a ordem, prevalecendo a decisão mais favorável ao paciente, devido ao empate em dois votos a dois. Votaram favoravelmente à concessão da ordem os Ministros William Patterson e Fontes de Alencar. Vencidos os Ministros Hamilton Carvalhido e Vicente Leal.

\title{
4.3. Emenda Constitucional $n^{0}$ 45/2004 e câmaras extraordinárias
}

Após a edição da Emenda Constitucional n ${ }^{\circ}$ 45/2004, a demanda referente ao rol de convocáveis nos Estados em que havia tribunal de alçada foi resolvida, eis que essas cortes foram abolidas.

Tal extinção ocorreu pois um dos objetivos precípuos da referida Emenda foi promover a celeridade processual, tendo sido previsto "um novo direito fundamental" ${ }^{134}$ no artigo $5^{\circ}$ da Lei Maior ${ }^{135}$, o direito à razoável duração do processo.

Como consequência disso, uma enorme quantidade de processos foi distribuída aos desembargadores dos tribunais de justiça, em especial, aos do Estado de São Paulo. Assim, principalmente em matéria penal ${ }^{136}$, passou-se a discutir a (in)viabilidade do julgamento desses processos em tempo razoável.

\footnotetext{
${ }^{134}$ Ressalte-se que a expressão, embora corrente, parece ser incorreta, pois, nas palavras de Rui Barbosa, "justiça atrasada não é justiça, senão injustiça qualificada". Ademais, o princípio da razoável duração do processo, como visto no tópico 3.5, já integrava a cláusula do devido processo legal.

${ }^{135}$ LXXVIII - a todos, no âmbito judicial e administrativo, são assegurados a razoável duração do processo e os meios que garantam a celeridade de sua tramitação.

${ }^{136}$ Em que se objetiva evitar a prescrição da pretensão punitiva do Estado e o excesso de prazo de prisões preventivas, entre outras consequências nefastas do julgamento tardio de processos penais.
} 
Com o intuito de resolver tal adversidade, o Sodalício bandeirante criou câmaras extraordinárias para o julgamento de processos penais, que eram compostas por três juízes convocados, inicialmente, em sistema de voluntariado, sendo presididas por desembargador sem voto.

Nessa toada, o assunto referente à violação do princípio do juiz natural, em decorrência da convocação de magistrados, passou a ser novamente suscitado perante o Supremo Tribunal Federal e o Superior Tribunal de Justiça, abarrotando-os de recursos e "remédios heroicos" sobre o assunto.

Em 2007, o tema foi apreciado pela Sexta Turma do Superior Tribunal de Justiça no Habeas Corpus $\mathrm{n}^{\circ} 72.941 / \mathrm{SP}^{137}$. No que interessa, o acórdão foi assim ementado:

PROCESSUAL PENAL. HABEAS CORPUS. CÂMARA FORMADA MAJORITARIAMENTE POR JUÍZES DE PRIMEIRO GRAU CONVOCADOS. VIOLAÇÃO AO PRINCÍPIO DO JUIZ NATURAL. OCORRÊNCIA.

1. Nulos são os julgamentos de recursos proferidos por Câmara composta, majoritariamente, por juízes de primeiro grau, por violação ao princípio do juiz natural e aos artigos 93, III, 94 e 98, I, da CF.

(...)

Em seguida, também a Quinta Turma do Superior Tribunal de Justiça firmou seu entendimento no mesmo sentido em relação ao sistema de convocação de juízes do Tribunal de Justiça do Estado de São Paulo. Eis a ementa do Habeas Corpus $\mathrm{n}^{\mathrm{o}} 98.796 / \mathrm{SP}^{138}$ :

\section{(...)}

1. Embora não exista impedimento à convocação, autorizada por lei complementar estadual, de Juízes de primeiro grau para compor órgão julgador do Tribunal de Justiça, não pode o órgão revisor ser formado majoritariamente por Juízes convocados, sob pena de violação ao princípio do Juiz Natural.

2. É dos Desembargadores titulares a jurisdição sobre os recursos criminais de competência do Tribunal de Justiça Estadual. A Constituição Federal admite a composição de órgão revisor formado por Juízes de primeiro grau somente para o julgamento dos recursos que versarem sobre crimes de menor complexidade e infrações de menor potencial ofensivo, de competência da Turma Recursal dos Juizados Especiais.

(...)

\footnotetext{
137 Relatora Ministra Maria Thereza de Assis Moura, Sexta Turma do Superior Tribunal de Justiça, julgado em 11.9.2007 e publicado no DJe de 19.11.2007.

${ }^{138}$ Relatora Ministra Laurita Vaz, Quinta Turma, julgado em 8.5.2008 e publicado no DJe de 2.6.2008.
} 
Posteriormente, a Terceira Seção do Tribunal ratificou o entendimento em relação aos juízes convocados, em sistema de voluntariado, na Corte paulista. O acórdão no Habeas Corpus $\mathrm{n}^{\mathrm{o}} 108.425 / \mathrm{SP}^{139}$ foi ementado nos seguintes termos:

PROCESSO PENAL. HABEAS CORPUS. TRIBUNAL DE JUSTIÇA DO ESTADO DE SÃO PAULO. LEI COMPLEMENTAR ESTADUAL No 646/90. CÂMARA COMPOSTA POR JUÍZES NÃO INTEGRANTES DO "QUADRO DE JUÍZES DE DIREITO SUBSTITUTOS EM SEGUNDO GRAU". SISTEMA DE VOLUNTARIADO. OFENSA AO PRINCÍPIO DO JUIZ NATURAL.

1. Não obstante a constitucionalidade do sistema de convocação de Juízes de primeiro grau para substituir Desembargadores do Tribunal de Justiça do Estado de São Paulo já reconhecido pelo Supremo Tribunal Federal, tal substituição, da maneira como vem sendo operada, não está de acordo com as regras da Lei Complementar $n^{\circ}$ 646/90, implicando ofensa ao princípio do juiz natural. (grifos apostos)

2. Substituição por juízes de primeiro grau de jurisdição não integrantes do "Quadro de Juízes Substitutos em Segundo Grau". Convocação de Juízes por meio de sistema de voluntariado.

3. Ordem concedida, para anular o julgamento da apelação criminal, determinando-se o seu julgamento por Câmara constituída de acordo com o disposto na Constituição Federal/88 e na Lei Complementar Estadual $\mathrm{n}^{\mathbf{o}}$ 646/90.

\subsection{Resolução $\mathbf{n}^{0} 72$ do Conselho Nacional de Justiça}

Após o Superior Tribunal de Justiça declarar a nulidade absoluta de diversos julgados do Sodalício bandeirante, o Conselho Nacional de Justiça publicou, em 31.3.2009, a Resolução $n^{\circ} 72$ - cuja entrada em vigor ocorreu na mesma data -, determinando a adaptação dos regimentos internos dos Tribunais às suas disposições no prazo de 90 (noventa) dias.

Consoante o disposto em seu artigo $2^{\circ}$, delimitou-se a atuação de juízes convocados em segunda instância a três hipóteses, tanto na Justiça Federal como na Estadual:

Art. $2^{\circ}$. A atuação de juízes de primeiro grau em segunda instância poderá decorrer:

I - do exercício do cargo de juiz substituto em segundo grau, de acordo com previsão legal específica, cujo provimento respeite as exigências constitucionais correspondentes;

\footnotetext{
139 Relator Ministro Og Fernandes, Terceira Seção, julgado em 24.9.2008 e publicado no DJe de
} 12.11.2008. 
II - da convocação para fins de substituição, de acordo com o art. 118 da LOMAN;

III - da convocação para fins de auxílio.

Nos casos de substituição e auxílio, a convocação deverá ocorrer da seguinte forma:

\begin{abstract}
Art. $7^{\circ}$. Quando expressamente autorizados por lei federal ou estadual própria, poderão ser convocados para substituição ou auxílio em segundo grau juízes integrantes da classe ou quadro especial de juízes substitutos de segundo grau quando houver, ou integrantes da entrância final ou única e titulares de juízos ou varas, e que preencham os requisitos constitucionais e legais exigidos para ocupar o respectivo cargo.
\end{abstract}

Depreende-se da parte final do artigo que o juiz convocado deverá preencher os requisitos legais e constitucionais exigidos para ocupar o cargo de desembargador ou desembargador federal.

Em razão de já terem percorrido as demais etapas da carreira e adquirido maior experiência, esses juízes convocados estariam aptos a ocuparem o cargo de desembargador definitivamente, motivo pelo qual não haveria nenhum óbice à ocupação provisória do cargo.

Observa-se, assim, que a Resolução aludida está em perfeita consonância com o entendimento anteriormente esposado pelo Ministro Sepúlveda Pertence no julgamento do Habeas Corpus 68.210/RS ${ }^{140}$ :

(...) não se compreende, com efeito, porque admitir a convocação, para substituição eventual no Tribunal de Justiça ou para ocupar-lhe provisoriamente as vagas, do juiz que, no escalonamento hierárquico da carreira, a ele não possa ter acesso definitivo.

$\mathrm{O} \S 2^{\circ}$ do $\operatorname{artigo} 7^{\circ}$ da Resolução determina, ainda, que os juízes convocados devem ficar afastados da jurisdição de suas respectivas unidades durante todo o período de convocação e que não poderão exercer outro encargo jurisdicional ou administrativo.

Além disso, a Resolução definiu que os colegiados dos tribunais devessem ser formados por maioria de desembargadores, conforme dispõe o artigo $10^{\circ}$ :

\footnotetext{
${ }^{140}$ Relator Ministro Sepúlveda Pertence, Tribunal Pleno, julgamento iniciado em 12.9.1990 e findo em 18.12.1991, publicado no DJ de 21.8.1992.
} 
Art. 10. As Câmaras ou Turmas dos Tribunais deverão ser formadas com maioria de desembargadores titulares e por um deles presidida, todos atuando como relator, revisor ou vogal.

Parágrafo único. Os juízes de primeiro grau convocados e os juízes substitutos em segundo grau designados integrarão as câmaras ou turmas para as quais forem destinados.

Verifica-se, portanto, que o Conselho Nacional de Justiça objetivou solucionar as questões referentes à formação de colegiados dos tribunais com juízes convocados, visto que a referida Resolução observou alegadas irregularidades que vinham sendo discutidas nos tribunais superiores.

Contra esta Resolução, a Associação Nacional de Desembargadores (ANDES) propôs a Ação Direta de Inconstitucionalidade $\mathrm{n}^{\circ}$ 4.314, com pedido de liminar, na qual alegou:

36. A resolução impugnada, ao disciplinar a convocação de juízes de primeiro grau para substituição e auxílio no âmbito dos Tribunais estaduais e federais, vulnerou o $\$ 4^{\circ}$ do artigo 103-B da Constituição Federal, porquanto o Conselho Nacional de Justiça ultrapassou os limites de sua missão constitucional de exercer o controle da atuação administrativa e financeira do Poder Judiciário. (grifos no original).

E contrariou, também frontalmente, os incisos I (alínea "a") e II (alíneas "b" e "d") do art. 96 do Texto Magno, que reserva competência exclusiva para que os tribunais estaduais e federais possam dispor sobre a competência e o funcionamento de seus órgãos jurisdicionais e administrativos. (grifos no original).

Com base nesses argumentos, requereu:

A procedência do pedido da ação direta, consistente na declaração de inconstitucionalidade formal (e/ou material) de todos os dispositivos da Resolução no 72/2009 do Conselho Nacional de Justiça, confirmando-se a liminar para os efeitos legais. (grifos no original).

O relator da ação, Ministro Joaquim Barbosa, proferiu decisão, adotando o rito revisto no artigo 12 da Lei 9.686/1999, em virtude da relevância da matéria. Após ser dado vista ao Advogado-Geral da União e ao Procurador Geral da República, aguarda-se o julgamento do pedido. 


\subsection{Recente tratamento da matéria pelo Supremo Tribunal Federal}

Diversos acórdãos acerca do assunto já haviam sido anulados pelo Superior Tribunal de Justiça mesmo antes da publicação da Resolução $\mathrm{n}^{\circ} 72$. Posteriormente, o tema foi levado a julgamento pela Primeira Turma do Supremo Tribunal Federal, nos autos do Habeas Corpus $\mathrm{n}^{\circ}$ 96.821/SP ${ }^{141}$, em 2.6.2009.

O Relator, Ministro Ricardo Lewandowski, proferiu voto denegando a ordem, apontando que a câmara composta majoritariamente por juízes convocados:

Evidentemente é um órgão criado oficialmente na estrutura do Tribunal de Justiça; as convocações são feitas por ato oficial; esses juízes servem permanentemente nessa Corte, portanto, não são designados ad hoc, são previamente designados; não é um juízo de exceção, que é proibido pela Constituição, em ofensa ao princípio do juiz natural.

O Ministro Marco Aurélio, em seguida, explicou que havia uma minúcia no sistema de substituição na Corte Bandeirante, a formação de câmaras extraordinárias ${ }^{142}$ :

Há uma peculiaridade: constitui-se, no Tribunal, uma nova câmara, que seria a $11^{\text {a }}$ Câmara Criminal "B", composta não de convocados para substituir desembargadores dessa câmara, mas de convocados para formá-la.

(...) ter-se-ia duas câmaras: a câmara propriamente dita, falaremos (...) que seria o órgão integrado ao Tribunal de Justiça e composto de desembargadores, e, paralelamente - prevalecendo o pragmatismo, ou seja, o número de processos liberados -, constitui-se um outro órgão.

Nesse passo, divergiu do Relator:

Não consigo agasalhar esse procedimento. Se pega, evidentemente, o princípio do juiz natural vai por água abaixo.

(...)

Uma coisa é convocar-se para substituição. Muito bem, o órgão não pode parar e a Lei Orgânica da Magistratura Nacional - artigo 118 - o autoriza. Agora, constituir um segundo órgão, com a consoante " $b$ " para designá-lo, e não se confundir com aquele que realmente integra o tribunal, é algo inconcebível.

\footnotetext{
${ }^{141}$ Relator Ministro Ricardo Lewandowski, julgamento iniciado em 2.6.2009, na Primeira Turma, e findo em 8.4.2010, no Tribunal Pleno, publicado no DJe de 25.6.2010.

${ }^{142}$ As câmaras extraordinárias no Tribunal de Justiça paulista foram compostas, em suma, da seguinte maneira: as câmaras criminais originárias (da primeira à décima primeira) foram subdivididas em " $\mathrm{A}$ ", "B", "C" e "D". As câmaras "A" mantiveram a formação das câmaras originárias. As câmaras "B", "C" e "D" foram formadas com juízes convocados, tendo sido apenas presididas por um desembargador, o presidente da câmara originária.
} 
Sustentando o seu entendimento, o Ministro Marco Aurélio ironizou:

Receio que, daqui a pouco, possamos ter $1^{\mathrm{a}}$ Turma do Supremo "B". Não consigo agasalhar essa dualidade.

Diante da divergência, o Relator propôs que a Turma ponderasse as consequências de uma eventual anulação do acórdão impugnado:

Peço apenas uma reflexão da colenda Turma no seguinte sentido: são centenas de milhares de decisões já proferidas pelo Tribunal de Justiça de São Paulo em matéria criminal, em mutirão feito para aliviar a situação dramática dos recursos criminais.

No mesmo sentido, a Ministra Cármen Lúcia aventou:

O Ministro Ricardo Lewandowski tem razão. É algo que preocupa, porque eles continuam julgando - são milhares de julgamentos -, e os interessados recorrem aos outros tribunais sob a mesma alegação de quebra do princípio do juiz natural.

Ato contínuo, o Ministro Ricardo Lewandowski, ex-Desembargador da Corte de Justiça do Estado de São Paulo, explicou o motivo da criação das câmaras extraordinárias:

(...) conheço bem o drama do meu tribunal de origem: depois da Emenda $\mathrm{n}^{\circ}$ 45 , que determinou a distribuição imediata de todos os feitos, criou-se um problema em matéria criminal: eram milhares, milhares e milhares de feitos distribuídos.

Nesse ponto, o Ministro Marco Aurélio contra-argumentou:

(...) o problema maior foi terem, contrariando a Lei Orgânica da Magistratura Nacional, estipulado uma cota máxima de processos para distribuição, o máximo de " $\mathrm{x}$ " processos por semana.

(...)

A bola de neve foi crescendo, crescendo, e, quando se viu... A LOMAN prevê a distribuição total e isso não foi observado.

Diante da complexidade do tema, de sua importância e do número de processos a esse respeito, a Primeira Turma do Supremo Tribunal Federal entendeu por bem deslocar para o Pleno a competência do writ, que foi levado a julgamento no dia 8.4.2010. 


\section{Em seu voto, o Ministro Ricardo Lewandowski ratificou o} entendimento por ele defendido perante a Primeira Turma, repisando as consequências decorrentes da extinção do Tribunal de Alçada do Estado de São Paulo:

(...) na situação específica de São Paulo, a EC 45/2004 determinou à Justiça bandeirante, a unificação dos Tribunais de Alçada com o Tribunal de Justiça, impondo-lhe a hercúlea tarefa de reorganizar administrativamente uma gigantesca Corte - que conta, atualmente, com 362 desembargadores e 60 juízes substitutos de segundo grau, além de um enorme número de servidores - de maneira a preservar, minimamente, a presteza e eficiência da prestação jurisdicional.

Em outras palavras, a EC 45/2004, ao estabelecer a unificação dos Tribunais paulistas, acarretou, além das mencionadas dificuldades, outra consequência de grande repercussão, a saber, a imediata transferência de um enorme estoque de feitos criminais, que antes se encontrava dividido entre duas Cortes, que tinha de ser imediatamente redistribuído.

Após, relatou as providências tomadas pelo Tribunal paulista:

O TJ/SP, com a diligência que lhe é peculiar, cumpriu, prontamente, a determinação do constituinte derivado, expedindo, em 26/4/2005, a Resolução 204, em que ordenou a imediata distribuição de todos os feitos aos desembargadores e juízes em segundo grau.

E, no mesmo ano de 2005, para dar conta do imenso acervo de processos que então acumulava, o Tribunal paulista criou câmaras extraordinárias, integradas, inicialmente, por juízes titulares da Capital e, depois, por juízes titulares do interior, da mesma entrância, presididas por um desembargador, que também atua como vogal ou terceiro juiz, a partir de edital de convocação, publicado no diário oficial (...).

O Relator ressalvou na ocasião que, não obstante ostentassem a denominação de convocados, os juízes participavam dos colegiados mediante inscrição voluntária.

Além disso, no que se refere à forma de convocação, mencionou que semelhante providência é adotada pela Justiça Federal, que se vale do permissivo do artigo $4^{\circ}$ da Lei $n^{\circ} 9.788 / 99^{143}$, não havendo notícia de que algum de seus julgados houvesse sido anulado.

Citou voto do Ministro Ayres Britto que, no julgamento do $\mathrm{HC} \mathrm{n}^{\circ}$ 84.414/SP, sustentou:

\footnotetext{
${ }^{143}$ Art. $4^{\circ}$ Os TRFs poderão, em caráter excepcional e quando o acúmulo de serviço o exigir, convocar juízes federais ou juízes federais substitutos, em número equivalente ao de juízes de cada tribunal, para auxiliar em segundo grau, nos termos de resolução a ser editada pelo Conselho da Justiça Federal.
} 
Quando a Turma julgadora é composta, na sua maioria, por convocados, há um risco de se fugir da tendência do Tribunal. Daí a dizer que o princípio constitucional do juiz natural restou vulnerado, parece-me que vai uma distância.

Em seguida, informou a produtividade das câmaras extraordinárias:

Vossas Excelências bem podem imaginar o impacto positivo que tal providência gerou para o bom andamento dos serviços, com particular benefício para os jurisdicionados. Eis os números: no período relativo aos anos de 2005 a 2010, até o mês de fevereiro, a produção das câmaras extraordinárias criminais correspondeu a $29 \%$ de todo o movimento das três Seções do Tribunal (Direito Público, Privado e Criminal), ou seja, 67.696, de um total de 233.419 processos $^{144}$.

São dados impactantes, que demonstram a necessidade premente de reorganização da máquina judiciária, mediante a criação, a todo o momento, de fórmulas que viabilizem o cabal desempenho do relevante múnus que a Constituição Federal atribui ao Poder Judiciário.

Quanto ao argumento dos impetrantes de que foi violada a proporção do quinto constitucional na composição das referidas câmaras, o relator aduziu que a suposta transgressão à regra constitucional não havia sido comprovada. Ao fim do voto, propôs ponderação entre o juiz natural e a segurança jurídica:

Permito-me, por fim, tecer uma derradeira consideração. Mesmo que se possa, apenas ad argumentandum tantum, entender que o princípio do juiz natural tenha sido de alguma forma malferido, cumpre proceder-se a uma necessária ponderação de valores - quiçá a mais nobre e delicada função do julgador -, contrastando o referido postulado com o da segurança jurídica. É que aqui se está a cogitar, ainda que indiretamente, de dezenas de milhares de decisões criminais, a maioria das quais já transitadas em julgado, que poderiam ser sumariamente anuladas, inclusive aquelas que concluíram pela absolvição dos réus. Ora, nesse sopesamento de normas com densidade axiológica equivalente, a meu sentir, há de prevalecer, no caso, o postulado da segurança jurídica.

Nesse passo, o Ministro votou pela denegação da ordem, tendo sido acompanhado pelos Ministros Cármen Lúcia, Ellen Gracie e Ayres Britto. Este último afirmou:

Entendo que a garantia do juiz natural decola ou arranca diretamente da Constituição, notadamente pela combinação dos incisos XXXVII e LIII do art. $5^{\circ}$.

Eu teria, portanto, Ministro Lewandowski, alguns questionamentos, algumas considerações de ordem técnica a tecer neste momento. Mas, atento às peculiaridades do caso, entendendo que Vossa Excelência fez um

\footnotetext{
${ }^{144}$ Dados obtidos na Secretaria Judiciária do TJ/SP - Seção de Estatística e Indicadores de Desempenho.
} 
equacionamento a partir de procedentes juízos de ponderação, acompanho o voto de Vossa Excelência.

O Ministro Marco Aurélio em seu voto valeu-se, novamente, de ironia para demonstrar sua indignação com a tese defendida pelo Relator:

\begin{abstract}
Questiono-me, a mim e apenas a mim: é legítima essa criação? Por que não partir-se, então, para a tomada desse exemplo, desse "bom exemplo", no próprio Supremo, criando-se, sem a previsão constitucional dos cargos, a Primeira Turma B, a Primeira Turma C, a Primeira Turma D, o mesmo ocorrendo com a Segunda? Por que não adotar essa prática também em relação ao Superior Tribunal de Justiça, que enfrenta avalanche insuplantável de processos e cujos integrantes são 33 e não 363, ou 364 desembargadores, como se tem em São Paulo? (...)
\end{abstract}

Após, afirmou ter ocorrido "acumulação imprópria", pois o convocado, além de atuar na função de desembargador, permanecia oficiando em primeira instância.

Tudo ocorreu com certo detalhe: a acumulação imprópria. O convocado continuava, mesmo integrando Câmaras criadas pelo Regimento Interno, oficiando na origem, ou seja, mostrava-se um juiz polivalente. A um só tempo era juiz e fazia as vezes de desembargador.

Finalizou seu voto consignando seu pedido de vênia para dissentir, com o desiderato de preservar a Constituição, descartando os argumentos pragmáticos em relação ao tema. E, por fim, divulgou rumor:

Já ouvi até dizerem que esses juízes seriam remunerados com um plus - não sei se é verdade, nisso não acredito - por processo liberado no Tribunal, considerado - parece - um máximo de trezentos processos por ano ${ }^{145}$.

Após, o Ministro Gilmar Mendes asseverou que já havia defrontado com o tema, em habeas corpus que ficou prejudicado, e na ocasião iria propor a declaração de inconstitucionalidade prospectiva, com o intuito de pôr fim à prática. Afirmou que as aludidas câmaras já haviam sido extintas no momento do julgamento em referência, motivo pelo qual não mais se recomendava a declaração de 145 A esse respeito, ver notícia veiculada em: http://www.conjur.com.br/2008-mar08/desembargador_paulista_nao_juizes_tribunal. De acordo com a reportagem, o Desembargador Luiz Pantaleão enviou ofício, em 3.3.2008, ao Presidente da Corte à época, no qual afirmou: “A remuneração dos Juízes de Direito convocados (sem prejuízo das suas Varas e Comarcas) define-se na cifra aproximada de R\$ 103,72 por voto, ou seja, R\$ 2.593,00 por mês (admitido o mínimo de 25 votos no período de trinta dias). Como a situação escapa às previsões da Lei Orgânica da Magistratura Nacional, a remuneração pode erroneamente confundir-se com verbas de diárias, diferença de entrância ou outro qualquer rótulo". 
inconstitucionalidade para o futuro. Assim, aduziu que acompanharia o relator no caso, por entender que a matéria já estava solucionada, embora simpatizasse com a tese do Ministro Marco Aurélio.

Também acompanharam o relator os Ministros Ayres Britto e Joaquim Barbosa. Nessa toada, o Pleno denegou a ordem do habeas corpus, por maioria, vencido o Ministro Marco Aurélio.

Observou-se no julgamento que diversos ministros seguiram o relator a despeito de concordarem com a tese sustentada pelo Ministro Marco Aurélio. Ao que parece, isso ocorreu em virtude da ponderação de valores proposta pelo Relator. Prevaleceu a segurança jurídica em relação ao juiz natural.

Em 17.10.2010, o Supremo Tribunal Federal discutiu novamente o assunto no Recurso Extraordinário $\mathrm{n}^{\circ}$ 597.133/RS ${ }^{146}$, também relatado pelo Ministro Ricardo Lewandowski, em relação a turmas compostas em maioria por convocados no Tribunal Regional Federal da $4^{\mathrm{a}}$ Região.

Na oportunidade, o Ministro Gilmar Mendes aduziu:

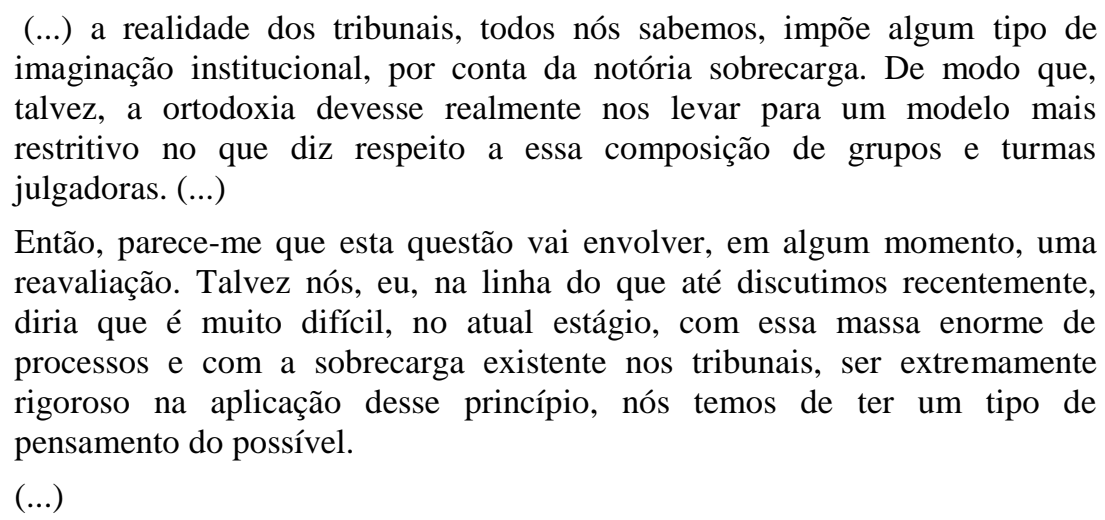

O Ministro Ricardo Lewandowski reforçou:

Colaborando no mesmo sentido do raciocínio desenvolvido por Vossa Excelência, é que os tribunais hoje estão espremidos, de um lado, pela chamada explosão de litigiosidade a que se referia o sociólogo português Boaventura Souza Santos (sic), de outro lado, pelo CNJ que exige meta de produção e, de outro lado, pelos recursos que são escassos, humanos e materiais. Então como diz Vossa Excelência, os tribunais estão engendrando soluções criativas, e essa é uma delas, e que têm inclusive base legal para poder enfrentar desafios.

\footnotetext{
${ }^{146}$ Relator Ministro Ricardo Lewandowski, Tribunal Pleno, julgado em 17.11.2010 e publicado no DJe de 6.4.2011.
} 
Na mesma linha, a Ministra Ellen Gracie afirmou que esta seria uma solução absolutamente transitória, justamente com o desiderato de permitir que o sistema voltasse à normalidade, por meio da aplicação de institutos como a repercussão geral e a súmula vinculante.

\section{O Ministro Gilmar Mendes então prosseguiu:}

Até porque sabemos bem que esta é uma crise que se agravou durante aí um longo período, mas que já existem agora mecanismos mais ou menos adequados para a resposta: a própria súmula vinculante, a ideia da repercussão geral, o modelo dos recursos repetitivos no âmbito do STJ, todos eles oferecem fórmulas para a solução, para a racionalização inclusive do nosso afazer.

A crise numérica é uma crise também de racionalidade. É preciso destacar. Então é preciso que haja uma solução. E sabemos também, especialmente na base da magistratura, a solução, em geral, encomendada e recomendada, é sempre aquela que envolve a expansão dos quadros, e nós sabemos que há limites para a expansão de tribunais, de quadro de servidores.

(...) é preciso que tenhamos cuidado em relação a esse tipo de situação e parece-me, então, que é importante fazermos esse tipo de juízo, sabendo que, no futuro, poderemos reavaliar o entendimento eventualmente hoje firmado.

Destarte, o Supremo Tribunal Federal negou provimento ao recurso por maioria, vencido novamente o Ministro Marco Aurélio. 


\section{Juízes convocados e os princípios do juiz natural e da razoável duração do processo}

Neste capítulo abordar-se-á o entendimento erigido - gradativamente ao longo desse trabalho - em relação aos três tópicos do capítulo antecedente, hipóteses em que se alegou violação ao princípio do juiz natural. Antes disso, faz-se necessário versar sobre o tema da ponderação entre os princípios do juiz natural e da razoável duração do processo no caso em análise.

Consoante se antecipou no tópico 3.5, a presteza na atividade jurisdicional não só é um valor desejável, como é conditio sine qua non para a pacificação social, desiderato almejado pela jurisdição ${ }^{147}$.

E o que se objetiva por meio da convocação de magistrados é justamente promover a razoável duração do processo. Nessa linha de ideias, Eduardo Yoshikawa assentou:

Com o propósito de resolver (ou pelo menos amenizar) o crônico problema na demora na entrega da prestação jurisdicional em segunda instância (uma apelação civil, em matéria não criminal, não raro demorava cinco anos para ser julgada), o Tribunal de Justiça de São Paulo, a partir de 2005, criou Câmaras Extraordinárias (designadas pelas letras "A", "B" etc.) presididas por um Desembargador e compostas exclusivamente por juízes de primeira instância $(. . .)^{148}$.

Assim, caso se entenda que viola o juiz natural a convocação em um determinado caso concreto, estar-se-á diante de uma hipótese em que será necessário ponderar os princípios do juiz natural e da razoável duração do processo, tendo em vista que, nessa situação, os dois apontarão para soluções opostas. Isso porque:

Em uma ordem democrática, os princípios freqüentemente entram em tensão dialética, apontando direções diversas. Por essa razão, sua aplicação deverá ocorrer mediante ponderação: à vista do caso concreto, o intérprete irá aferir o peso que cada princípio deverá desempenhar na hipótese, mediante concessões recíprocas, e preservando o máximo de cada um, na medida do possível $^{149}$.

\footnotetext{
${ }^{147}$ Conforme ARAÚJO CINTRA; GRINOVER; DINAMARCO (2007, p. 30): “A pacificação é o escopo magno da jurisdição e, por consequência, de todo o sistema processual (uma vez que todo ele pode ser definido como a disciplina jurídica da jurisdição e seu exercício)”. (Grifos no original).

${ }^{148}$ YOSHIKAWA (2008, p. 29).

${ }^{149}$ BARROSO (2009, p. 354).
} 
Ocorre que, consoante já se defendeu no tópico 3.5, o ideal de promover celeridade para garantir a razoável duração do processo, ainda que fundado na melhor das intenções, deve ser limitado pela proteção das garantias processuais das partes, entre as quais está o princípio-garantia do juiz natural, um dos "princípios da mais antiga tradição em nosso direito constitucional"150.

Por essa razão, entende-se que a solução dos casos nos quais se verifique a violação da garantia do juiz natural deverá pender para o sentido em que seja assegurada sua efetiva aplicação, mesmo que isso implique desfavorecer o louvável escopo de celeridade. Isso porque, em última instância, o que estará em jogo será "o direito dos jurisdicionados de terem a sua causa julgada (...) por juízes competentes, conforme determina a lei”, ${ }^{, 151}$.

Partindo dessa ponderação de princípios, passa-se a examinar a eventual violação do princípio do juiz natural nas situações julgadas pelo Supremo Tribunal Federal e pelo Superior Tribunal de Justiça, referentes à convocação de magistrados.

A análise será dividida em três tópicos distintos, seguindo a ideia do capítulo anterior. Não obstante as três hipóteses envolvam argumentos diversos em essência, ao examinar os julgados, notou-se que, mais de uma vez, os contextos e fundamentações foram imbricados.

Em específico, a declaração da constitucionalidade, pelo Pretório Excelso, do sistema de convocações estabelecido em São Paulo não significa que a própria lei instituidora desse sistema (Lei Complementar estadual $n^{\circ}$ 646/90) tenha sido observada. Na Corte bandeirante, além da atuação dos juízes substitutos em segundo grau, cujo cargo foi previsto na referida lei, houve a atuação de juízes de primeira instância ocupantes de cargo da entrância final.

Nesse sentido, o Comunicado $\mathrm{n}^{\circ}$ 05/08 do Tribunal paulista, publicado no Diário de Justiça Eletrônico de 16.1.2008, dispôs:

\footnotetext{
A Presidência do Tribunal de Justiça do Estado de São Paulo comunica que, considerando o acervo de processos distribuídos para julgamento em $2^{\mathrm{a}}$ instância, convocará Magistrados de $1^{\text {a }}$ Instância ocupantes de cargo de entrância final para, sem prejuízo do cargo de que seja titular, integrar
}

\footnotetext{
${ }^{150}$ BOTELHO DE MESQUITA apud YOSHIKAWA (2008, p. 34).

${ }^{151}$ YOSHIKAWA (2008, p. 34).
} 
Câmaras que serão formadas para auxiliar no julgamento dos referidos processos.

Além disso, a irregularidade das convocações não significa, por si só, a proibição de que os órgãos fracionários sejam compostos majoritariamente por juízes convocados.

\subsection{Juízes convocados nos Estados em que havia tribunal de alçada}

Primeiramente, cumpre observar que o assunto deste tópico perdeu considerável importância prática em virtude da extinção dos tribunais de alçada. No entanto, persiste o seu valor teórico, motivo pelo qual se passa a analisá-lo.

Em relação a essa matéria, a LOMAN expressamente previa, em seu artigo $118, \S 1^{\circ}$, III $^{152}$, que a convocação - para substituir magistrados de tribunal de justiça dos Estados - far-se-ia dentre os membros do tribunal de alçada, onde houvesse.

O dispositivo da lei, ao que parece, não dava margem para dúvidas interpretativas. No entanto, ainda que o referido artigo não existisse, o que se cogita para argumentar, os artigos 93, III, da Lei Maior ${ }^{153}$ e 100 da LOMAN $^{154}$ já previam a lógica de acesso aos tribunais de justiça estaduais.

Tais artigos dispõem que o acesso se dá por membros ocupantes do cargo imediatamente inferior, em hierarquia, ao de desembargador. A ideia basilar é a de que o juiz, para ser promovido a desembargador, deve estar apto a fazê-lo, em razão

\footnotetext{
152 Art. 118. Em caso de vaga ou afastamento, por prazo superior a 30 (trinta) dias, de membro dos Tribunais Superiores, dos Tribunais Regionais, dos Tribunais de Justiça e dos Tribunais de Alçada, (vetado) poderão ser convocados Juízes, em substituição (vetado) escolhidos (vetado) por decisão da maioria absoluta do Tribunal respectivo, ou, se houver, de seu Órgão Especial: (Redação dada pela Lei Complementar $\mathrm{n}^{\circ} 54$, de 22.12.1986) $\S 1^{\circ}$ A convocação far-se-á mediante sorteio público dentre: (...) III - Os Juízes da Comarca da Capital para os Tribunais de Justiça dos Estados onde não houver Tribunal de Alçada e, onde houver, dentre os membros deste para os Tribunais de Justiça e dentre os Juízes da Comarca da sede do Tribunal de Alçada para o mesmo; (grifos apostos).

${ }^{153}$ Art. 93. Lei complementar, de iniciativa do Supremo Tribunal Federal, disporá sobre o Estatuto da Magistratura, observados os seguintes princípios: (...) III - o acesso aos tribunais de segundo grau far-se-á por antiguidade e merecimento, alternadamente, apurados na última entrância ou, onde houver, no Tribunal de Alçada, quando se tratar de promoção para o Tribunal de Justiça, de acordo com o inciso II e a classe de origem; (grifos apostos).

${ }^{154}$ Art. 100. Na composição de qualquer Tribunal, um quinto dos lugares será preenchido por advogados, em efetivo exercício da profissão, e membros do Ministério Público, todos de notário merecimento e idoneidade moral, com dez anos, pelo menos, de prática forense. (...) $§ 3^{\circ}$ Nos Estados em que houver Tribunal de Alçada, constitui este, para efeito de acesso ao Tribunal de Justiça, a mais alta entrância da Magistratura estadual. (grifos apostos).
} 
de já ter exercido os cargos anteriores da carreira e idealmente adquirido experiência e maturidade para tal.

Ora, a inteligência do raciocínio absorvido pela Carta Magna e pela LOMAN aplica-se a todos os casos de acesso aos tribunais de justiça estaduais, independente de ser definitivo ou provisório. Em outras palavras, não importa se o acesso ocorre em decorrência de promoção, substituição ou auxílio. O que realmente importa é que, para exercer o cargo de desembargador, mesmo que temporariamente, o magistrado já esteja em condições de exercê-lo definitivamente.

Nessa linha de argumentos, vale repisar o afirmado pelo Ministro Sepúlveda Pertence ${ }^{155}$ :

(...) não se compreende, com efeito, porque admitir a convocação, para substituição eventual no Tribunal de Justiça ou para ocupar-lhe provisoriamente as vagas, do juiz que, no escalonamento hierárquico da carreira, a ele não possa ter acesso definitivo.

Ao defender tese contrária, o Ministro Carlos Velloso aduziu no julgamento do mesmo writ:

\begin{abstract}
(...) não me parece que um critério regulador de acesso, por promoção, deva prevalecer também na hipótese de convocação de substituto eventual de desembargador, em que predomina (sic), de regra, razões de conveniência administrativa. Se fosse possível ao Tribunal de Justiça examinar e modificar decisões do Tribunal de Alçada, haveria o argumento, em favor da prevalência da regra do art. 93, III, da inconveniência, sob o ponto de vista de política judiciária, de um juiz de entrância inferior ao Tribunal de Alçada rever decisões deste. Isto, entretanto, não ocorreria, dado que, sob tal aspecto, o Tribunal de Alçada não está sujeito ao Tribunal de Justiça, já que suas decisões são recorríveis para o Superior Tribunal de Justiça ou para a Corte Suprema, nos casos especificados na Lei Maior.
\end{abstract}

Entendeu-se, ao cabo deste estudo, que a tese defendida pelo Ministro Sepúlveda Pertence é a que melhor se coaduna com o espírito do artigo 93, III, da Constituição Federal com a redação vigente à época.

Ao contrário do entendimento esposado pelo Ministro Carlos Velloso, sustenta-se que o sistema de convocação deve ser precisamente descrito em lei, não se deixando qualquer margem para que a convocação ocorra com base em conveniência administrativa.

155 Habeas Corpus $\mathrm{n}^{\mathrm{o}}$ 68.210/RS, Relator Ministro Sepúlveda Pertence, Tribunal Pleno do Supremo Tribunal Federal, julgamento iniciado em 12.9.90, findo em 18.12.1991, publicado no DJ de 21.8.1992. 
Defende-se que, na convocação de magistrados, não deva existir discricionariedade por parte do tribunal ad quem. Assim, os juízes deveriam ser designados rigorosamente na ordem em que figuram na lista para promoção ao cargo de desembargador ${ }^{156}$. Dessa forma, a convocação atenderia aos preceitos de transparência e previsibilidade, evitando-se manipulação na escolha de convocados.

Tais preceitos, no caso, têm exatamente o objetivo de prestigiar o princípio-garantia do juiz natural. Conforme advertiu Schwab em palestra proferida no Brasil:

\begin{abstract}
$\mathrm{Na}$ República Federal da Alemanha o princípio do juiz natural é compreendido em sentido abrangente. Em um número muito grande de decisões, o Tribunal Constitucional Federal tem-se ocupado da interpretação do artigo 101, I, 2, da Lei Fundamental. Assim se observa de uma decisão de 1964:

'Juiz natural no sentido desta norma é não somente o tribunal como unidade organizada ou o tribunal reconhecido como órgão judicante, perante o qual um caso concreto é processado e julgado, mas são também os juízes competentes para a decisão de um caso individual. Está é, portanto, a finalidade do comando do artigo (...)'.

Disse o Tribunal Federal Constitucional que o artigo (...) tem como objetivo evitar o perigo de a justiça, por intermédio de manipulação externa ou interna dos órgãos judicantes, se expor a influências estranhas, especialmente no que concerne ao caso concreto, com a possibilidade de que se influencie no resultado da decisão, através da escolha de um juiz ad hoc como o competente $^{157}$. (grifos no original).
\end{abstract}

No sentido de reforçar o que ora se argumenta, o Supremo Tribunal Federal, nos autos da Ação de Declaração de Inconstitucionalidade no 813-7/SP ${ }^{158}$, decidiu que não haveria listas sêxtuplas para o tribunal de justiça nos Estados em que havia tribunal de alçada, visto que as vagas reservadas ao quinto constitucional daquelas cortes deveriam ser preenchidas por membro desta, oriundos da advocacia e do Ministério Público. Ementou-se:

CONSTITUCIONAL. QUINTO CONSTITUCIONAL. TRIBUNAL DE JUSTIÇA. TRIBUNAL DE ALÇADA. LISTA SÊXTUPLA. CONSTITUIÇÃO DO ESTADO DE SÃO PAULO, ARTIGO 63, $\S 3^{\circ}$. CONSTITUIÇÃO FEDERAL, ARTIGO 93, III, ARTIGO 94.

\footnotetext{
${ }^{156}$ Diante da dificuldade de se avaliar previamente as futuras promoções pelo critério do merecimento, poder-se-ia, nas convocações, adotar apenas o critério da antiguidade. Nesse sentido, o artigo 42 do Regimento Interno do Tribunal de Justiça do Distrito Federal e Territórios dispõe: "Em caso de afastamento de desembargador - a qualquer título, por período superior a trinta dias - e de vacância do cargo, serão convocados juízes de direito para substituição nas Câmaras e nas Turmas, observada a ordem decrescente de antiguidade entre os juízes de direito.

${ }^{157}$ SCHWAB (1987, p. 38).

${ }^{158}$ Relator Ministro Carlos Velloso,Tribunal Pleno, julgada em 9.6.1994 e publicada no DJ de 17.6.1994.
} 
I. - Os juízes do quinto constitucional, nos Tribunais de Alçada, conservam, para promoção ao Tribunal de Justiça, a classe advinda da origem (CF, art. 93, III). Isto quer dizer que as vagas dessa natureza, ocorridas no Tribunal de Justiça, serão providas com integrantes dos Tribunais de Alçada, pertencentes à mesma classe, pelos critérios de antiguidade e merecimento, alternadamente. Nos Estados, pois, em que houver Tribunal de Alçada, não haverá listas sêxtuplas para o Tribunal de Justiça, dado que o ingresso neste, pelo quinto constitucional, ocorrerá naquela Corte, vale dizer, no Tribunal de Alçada.

II. - Interpretação harmônica do disposto no art. 93, III, e art. 94, da Constituição Federal.

III. - Constitucionalidade do $\S 3^{\circ}$ do art. 63 da Constituição do Estado de São Paulo.

IV. - Ação direta de inconstitucionalidade julgada improcedente.

No entanto, nesta hipótese específica, impende ressalvar argumento, em sentido contrário, defendido pelo Ministro Moreira Alves no julgamento, em que foi voto vencido:

\begin{abstract}
O quinto constitucional não se destina a prejudicar os juízes de carreira ou a beneficiar advogados e membros do Ministério Público, mas, sim, a permitir que na composição do Tribunal haja juízes de origem profissional diversa, que possam, assim, carrear para as decisões coletivas as experiências e os modos de ver de sua formação funcional. Essa finalidade que levou a Constituição a determinar a existência do quinto nos Tribunais a que alude a Carta Magna evidentemente não é respeitada se se admite que o acesso de Tribunal de Alçada para o Tribunal de Justiça se faça, no quinto deste, não por advogados e membros do Ministério Púbico, mas por juízes daquele que nele ingressaram nessa condição, e que, obviamente, com tal investidura deixaram de ser advogados ou membros do Ministério Público. Com isso não se atende, evidentemente, ao objetivo da Constituição, até porque, no fim de vários anos de exercício no Tribunal de Alçada, o juiz advindo da advocacia ou do Ministério Público já se tornou profissionalmente um juiz, não mais conservando, em boa parte, aqueles atributos proveniente de sua origem.
\end{abstract}

O entendimento firmado neste trabalho constitui uma dificuldade do ponto de vista prático: a convocação de juiz do tribunal de alçada para o tribunal de justiça poderia acarretar mais uma convocação, para suprir a vaga deixada pelo juiz de alçada em sua corte de origem.

De fato, trata-se de um argumento de destacada relevância, mas se entende que, por si só, seja insuficiente para que se permitisse a convocação de juiz da comarca da capital para substituir diretamente no tribunal de justiça, sem antes ser promovido ao tribunal de alçada. 


\subsection{Câmaras Extraordinárias e Turmas Suplementares}

Quanto aos órgãos fracionários constituídos temporariamente com a finalidade específica (ad hoc) de reduzir o número de processos represados em determinada Corte, cumpre ressaltar que foi apresentado, no tópico 4.3., apenas o exemplo das câmaras extraordinárias no Tribunal de Justiça do Estado de São Paulo. A despeito disso, há notícias de casos similares, como é o das atuais turmas suplementares do Tribunal Regional Federal da $1^{\text {a }}$ Região ${ }^{159}$.

A esse respeito, o Desembargador Federal aposentado Carlos Fernando Mathias manifestou ${ }^{160}$, quando atuava como convocado no Superior Tribunal de Justiça, em caso no qual se alegava violação à garantia do juiz natural:

(...) esse sempre foi o meu modesto voto quando o meu Tribunal (...) criou as turmas suplementes, opus-me e nunca mandei um processo sequer para as turmas suplementares.

(...)

São todos jovens, com muito talento - nenhum reparo quanto a isso - mas exatamente o princípio do juízo natural que era afetado e não sei até como o Ministério Público, nem a Ordem dos Advogados do Brasil não avançou nisso, porque fere o princípio do juízo natural e toda a história do Direito. A declaração dos direitos dos homens e do cidadão já dizia como garantia que ninguém poderá ser julgado a não ser por um juiz natural.

A propósito, membro da própria Corte bandeirante também se insurgiu contra as câmaras extraordinárias:

(...) conforme noticiado pela imprensa, o Exmo. Sr. Desembargador Luiz Pantaleão, do Tribunal de Justiça, tomou a louvável iniciativa de encaminhar ofício ao Presidente da Corte Paulista, requerendo a imediata suspensão da atividade dos magistrados convocados, a dissolução das Câmaras compostas de juízes de primeira instância e a redistribuição dos processos pendentes de julgamento aos efetivos integrantes do tribunal (desembargadores e juízes substitutos em segundo grau).

(...) aduz o magistrado que esta convocação representou a criação de um "tribunal paralelo", praticamente um tribunal de exceção, "repelindo o princípio do juízo natural e do efetivo duplo grau de jurisdição" (...). ${ }^{161}$

\footnotetext{
${ }^{159}$ Conforme notícia veiculada no endereço eletrônico do Superior Tribunal de Justiça, o assunto está sendo julgado, por sua Quinta Turma, nos autos dos Habeas Corpus n ${ }^{\circ}$ 121.827/GO e 124.676/GO. Ver: http://www.stj.gov.br/portal_stj/publicacao/engine.wsp?tmp.area=398\&tmp.texto=101672. Acesso em: 16.6.2010.

160 Voto no HC 72.941/SP, Relatora Ministra Maria Thereza de Assis Moura, Sexta Turma do Superior Tribunal de Justiça, julgado em 11.9.2007 e publicado no DJe de 19.11.2007.

${ }^{161}$ YOSHIKAWA (2008, p. 22).
} 
Ao longo deste estudo, edificou-se o entendimento de que, nesses casos específicos, há violação ao princípio do juiz natural, embora deva ser exaltado o nobre escopo de assegurar, por meio das convocações, a razoável duração do processo e, por conseguinte, o devido processo legal.

Para melhor examinar o assunto, as referidas câmaras extraordinárias e turmas suplementares serão analisadas separadamente, tendo em vista que ambas têm previsões normativas diversas.

\subsubsection{Câmaras Extraordinárias no TJSP}

O princípio-garantia do juiz natural, interpretado restritivamente, significaria tão somente a impossibilidade de instituir tribunal estranho à organização judiciária para julgar fato anterior a sua constituição, cujo exemplo grotesco é o Tribunal Militar Internacional, abordado no tópico 2.3.

Ao que parece, o ministro Ricardo Lewandowski interpretou o princípio de forma circunscrita ao analisar as câmaras extraordinárias nos seguintes termos:

Evidentemente é um órgão criado oficialmente na estrutura do Tribunal de Justiça; as convocações são feitas por ato oficial; esses juízes servem permanentemente nessa Corte, portanto, não são designados ad hoc, são previamente designados; não é um juízo de exceção, que é proibido pela Constituição, em ofensa ao princípio do juiz natural.

Em sentido oposto, verificou-se nesse estudo que o citado princípio proíbe, em sua gênese, a evocação, ou seja, a derrogação de competência. Nessa linha de argumentos:

Também se manifesta a violação a este aspecto do princípio do juiz natural [o poder de evocação] quando, mesmo existindo previamente o órgão julgador, para ele são designadas pessoas não investidas de acordo com o ordenamento constitucional $^{162}$.

Era exatamente isso o que ocorria nas câmaras extraordinárias ${ }^{163}$, pois, apesar de apenas as câmaras criminais numeradas de 1 a 11 serem competentes para

\footnotetext{
162 CONEGLIAN (2008, p. 160).

${ }^{163}$ Exceto quanto à existência prévia do órgão julgador, o que agrava a violação nesse caso.
} 
julgar os processos criminais distribuídos à Corte bandeirante, também os julgavam as câmaras extraordinárias.

A Lei Complementar do Estado de São Paulo n ${ }^{\circ}$ 646/90 foi declarada constitucional pelo Pretório Excelso ${ }^{164}$. Essa lei previu a criação de um quadro permanente de 60 (sessenta) juízes de direito substitutos em segundo grau e, além disso, dispôs:

Artigo $2^{\circ}$ - Por designação do Presidente do Tribunal de Justiça, os Juízes de Direito Substitutos em Segundo Grau substituirão membros dos Tribunais ou nele auxiliarão, quando o acúmulo de feitos evidenciar a necessidade de sua atuação.

Parágrafo único - A designação para substituir ou auxiliar nos Tribunais de Alçada será realizada mediante solicitação das respectivas Presidências.

Ocorre que o sistema de substituição promovido nas câmaras extraordinárias dissentia consideravelmente do que houvera sido previsto nessa lei, o que infringia também o disposto nos artigos $107^{165}$ e $118^{166}$ da Lei Complementar $n^{\circ} 35$ (LOMAN).

Em primeiro lugar, o artigo 107 veda a convocação ou designação de juiz para exercer cargo ou função nos tribunais, por outra forma que não seja a substituição ocasional de desembargadores. Assim, não poderia uma lei complementar estadual (como fez a referida lei paulista) criar o instituto do auxílio, em contraposição ao prescrito na LOMAN.

Nesse sentido, o Ministro Marco Aurélio decidiu pela inconstitucionalidade do auxílio:

\begin{abstract}
Surge, à primeira vista, conflitante com o texto constitucional, revelando rotundo desvio de função, previsão no sentido de convocar-se Juízes para atuarem como verdadeiros assessores, muito embora utilizado sutil jogo de palavras, afirmando-se que serão auxiliares dos Juízes que integram o Tribunal. A lei não pode fazer de um Juiz um auxiliar, um assessor de quem quer que seja. E o pior, “descobrindo um santo para cobrir outro". Explico: passa-se a ter um Juiz sem Vara, à margem da atuação que lhe é própria, deslocado de suas funções, ausente, consideradas as atribuições do cargo
\end{abstract}

\footnotetext{
164 No HC 69.601/SP, Primeira Turma, Relator Ministro Celso de Mello, julgado em 24.11.1992 e publicado no DJ de 18.12.1992.

${ }^{165}$ Art. 107 - É vedada a convocação ou designação de Juiz para exercer cargo ou função nos Tribunais, ressalvada a substituição ocasional de seus integrantes (art. 118).

166 Art. 118. Em caso de vaga ou afastamento, por prazo superior a 30 (trinta) dias, de membro dos Tribunais Superiores, dos Tribunais Regionais, dos Tribunais de Justiça e dos Tribunais de Alçada, (Vetado) poderão ser convocados Juízes, em Substituição (Vetado) escolhidos (Vetado) por decisão da maioria absoluta do Tribunal respectivo, ou, se houver, de seu Órgão Especial.
} 
previstas na Carta Federal. O procedimento prejudica a área que aponto como pedreira da magistratura - a primeira instância - e, consequentemente, os jurisdicionados. Tudo isso ocorre a pretexto de agilitarem-se os trabalhos nos Tribunais, pouco importando o meio, pouco importando a gritante inversão de valores. Passa-se a ter o Juiz-assessor, o Juiz-auxiliar, figuras que talvez somente gerem uma vantagem - e mesmo assim creio-a infrutífera, presente o apego maior a princípios -, a convivência estreita com a cúpula do poder, quiçá lubrificando as engrenagens de uma carreira profissional célere.

(...)

O que se dirá do implemento de verdadeira sobreposição revelada pelo fato de, sem o afastamento do titular considerada causa prevista na LOMAN, o convocado fazer as vezes deste, inclusive comparecendo a sessões, em desprezo total, nesse caso, ao princípio do Juiz natural ${ }^{167}$.

Nesse ponto, o Ministro mostrou-se coerente ao não indicar juiz para auxiliá-lo, conforme reportagem ${ }^{168}$ na qual se relatou:

Marco Aurélio estava chateado com uma pesquisa divulgada na imprensa sobre a lentidão do STF, na qual ele não figurava entre os mais rápidos. "A batalha para combinar conteúdo e celeridade é inglória", disse. "Eu não entro na competição de quantidade, e não aceito que juízes auxiliares julguem os meus casos. Acho que o ofício de julgar é indelegável, porque não basta a formação técnica. A formação humanística é mais importante.”

Juízes auxiliares foram introduzidos no Supremo Tribunal Federal, por maioria de votos, numa reunião administrativa, durante a presidência de Nelson Jobim. Achou-se que eles ajudariam a dar conta das montanhas de processos - quase 10 mil por ministro, vale lembrar. $\mathrm{O}$ regimento passou a estipular que um ministro tem direito a um juiz auxiliar, em cargo de confiança, que requisita de outros tribunais, a seu exclusivo critério. Nove ministros têm juiz auxiliar. Marco Aurélio e Celso de Mello, que são contrários, nunca indicaram os seus. Essa sobra, por assim dizer, foi reivindicada por Ellen Gracie, que queria ficar com três só para ela. Numa sessão administrativa, seu pedido foi posto em votação e recusado.

Em segundo lugar, a substituição, prevista no artigo 118, deve ser ocasional, podendo ocorrer apenas quando houver vaga ou afastamento de membro de tribunal por prazo superior a 30 (trinta) dias. Absolutamente distinto era o sistema instituído pela Corte bandeirante a partir de 2005, a que Eduardo Yoshikawa ${ }^{169}$ batizou de "mutirões ${ }^{170}$ de convocados".

\footnotetext{
${ }^{167}$ Trecho da decisão monocrática proferida, em 20.2.2010, nos autos do MS no 28.627/DF.

168 Reportagem: Data Venia, o Supremo. Revista Piauí, Edição no 47 . Disponível em: http://revistapiaui.estadao.com.br/edicao-47/questoes-juridicas/data-venia-o-supremo. Acesso em 21.6.2011.

169 YOSHIKAWA (2008, p. 31).

${ }^{170}$ A respeito dos mutirões de Juízes, Luiz Flávio Gomes já havia advertido: “Considerando a garantia do juiz natural (...), só cabe concluir pela inconstitucionalidade da designação de Juiz Titular da Vara Criminal de São Paulo para atuar em processos que correm pela Vara de Execuções Criminais", muito embora fosse elogiável o propósito das designações, de apreciar uma grande quantidade de pedidos de benefícios de réus presos. GOMES (1994, p. 422).
} 
As convocações para essas câmaras não se destinavam à substituição de desembargadores, nem sequer a auxiliá-los. Tinham a finalidade específica de formálas.

Ademais, as câmaras extraordinárias eram compostas por juízes voluntários e, não, por juízes substitutos em segundo grau, cujos cargos haviam sido previstos em lei ${ }^{171}$, conforme determina o princípio do juiz natural.

Consoante assentou a Ministra Maria Thereza de Assis Moura, em seu voto, no paradigmático caso analisado pelo Superior Tribunal de Justiça ${ }^{172}$ :

\begin{abstract}
Mesmo que se admita a convocação de juízes de primeiro grau para atuar em segunda instância, nos termos do disposto na Lei Complementar estadual $\mathrm{n}^{\circ}$ 646/90, a atuação destes, não se pode olvidar, é voltada à substituição e ao auxílio dos desembargadores. Isto significa que: i) ou os juízes convocados deverão atuar no lugar deixado pelos desembargadores substituídos, ocupando o lugar deixado por estes na Turma, mesclando-se, portanto, aos demais desembargadores; ii) ou os juízes convocados deverão auxiliar os desembargadores, para evitar o acúmulo de serviço.
\end{abstract}

No que se refere às substituições, concorda-se com a tese defendida pela Ministra. A criação de cargos só pode ocorrer por meio de lei. Assim, é vedado aos tribunais criar cargos de juízes convocados para substituir em segunda instância com base em seus atos internos.

\title{
Conforme afirmou Coneglian:
}

(...) há que se destacar que, impreterivelmente, a competência só pode ser fixada por lei ou pela Constituição, não sendo constitucionais os casos em que há criação de Varas ou Secções Judiciárias por atos internos dos Tribunais ${ }^{173}$.

Desse modo, no âmbito do Tribunal de Justiça do Estado de São Paulo, só se deveria permitir a substituição em segunda instância estritamente conforme a previsão da citada lei complementar estadual, na parte em que observou a LOMAN.

Assim, a convocação só poderia ocorrer para substituição de desembargadores (e não para auxílio) e só poderiam ser convocados juízes substitutos em segundo grau, cargo criado pela Lei Complementar estadual (e não qualquer juiz voluntário da última entrância).

\footnotetext{
${ }^{171}$ A Lei Complementar estadual no 646/90.

${ }^{172}$ Voto no HC 72.941/SP, Relatora Ministra Maria Thereza de Assis Moura, Sexta Turma do Superior Tribunal de Justiça, julgado em 11.9.2007 e publicado no DJe de 19.11.2007.

${ }^{173}$ CONEGLIAN (2008, p. 161)
} 


\title{
5.2.2. Turmas Suplementares no TRF da Primeira Região
}

\author{
Na seara da Justiça Federal, a Lei 12.011/09 ${ }^{174}$ dispôs:
}

Art. $4^{\circ}$ Os Tribunais Regionais Federais poderão, em caráter excepcional e quando o acúmulo de serviço o exigir, convocar Juízes Federais ou Juízes Federais Substitutos, em número equivalente ao de Juízes de cada Tribunal, para auxiliar em Segundo Grau, nos termos de resolução a ser editada pelo Conselho da Justiça Federal.

De acordo com essa lei ordinária, os juízes federais e os juízes federais substitutos poderiam atuar em segundo grau auxiliando desembargadores. $\mathrm{O}$ auxílio, no entanto, contraria o disposto no artigo 107 da LOMAN, que é lei complementar.

Há, nesse caso, conflito entre os dispositivos de lei complementar e lei ordinária. Assim, faz-se necessário analisar a consequência desse conflito:

Conquanto juristas de nomeada entendam haver hierarquia entre lei ordinária e lei complementar, melhores razões parecem assistir a Michel Temer, quando aponta que "não há hierarquia alguma entre a lei complementar e a lei ordinária. O que há são âmbitos materiais diversos atribuídos pela Constituição a cada qual destas espécies normativas".

A lei ordinária que destoa da lei complementar é inconstitucional por invadir o âmbito normativo que lhe é alheio, e não por ferir o princípio da hierarquia das leis. Por outro lado, não será inconstitucional a lei ordinária que dispuser em sentido diverso do que estatui um dispositivo de lei complementar que não trata de assunto próprio de lei complementar. O dispositivo da lei complementar, no caso, vale como lei ordinária e pode-se ver revogado por regra inserida em lei ordinária. Nesse sentido é a jurisprudência do STF ${ }^{175}$.

Dessa forma, para examinar a constitucionalidade do auxílio, é preciso analisar se o referido artigo 107 trata de assunto próprio de lei complementar ou não, com base no caput do artigo 93 da Constituição Federal ${ }^{176}$ e seus incisos, que descrevem os princípios a serem observados pelo Estatuto da Magistratura.

Entende-se, neste trabalho, que o artigo 107 não escapa ao domínio inerente às leis complementares, o que, a princípio, torna inconstitucional o artigo $4^{\circ}$ da

\footnotetext{
${ }^{174}$ Reproduzindo o teor do artigo $4^{\circ}$ da Lei 9.788/99.

${ }^{175}$ MENDES; COELHO; e GONET BRANCO (2007, p. 836).

${ }^{176}$ Art. 93. Lei complementar, de iniciativa do Supremo Tribunal Federal, disporá sobre o Estatuto da Magistratura, observados os seguintes princípios: (...).
} 
Lei 12.011/09, conforme a citada doutrina de Gilmar Ferreira Mendes, e o entendimento do Ministro Marco Aurélio, acima exposto.

No entanto, ainda que se entenda que o artigo 107 extrapola o âmbito de competência das leis complementares, não se poderá considerar válida a convocação de juízes federais na forma pela qual vem sendo feita no Tribunal Regional Federal da $1^{\text {a }}$ Região.

Quer dizer, ainda que o referido artigo $4^{\circ}$ seja considerado constitucional (por não invadir âmbito normativo de lei complementar), o seu dispositivo não tem sido observado em relação aos convocados das turmas suplementares.

Isso porque o artigo $4^{\circ}$ prevê tão somente o auxílio dos convocados, o que significa que eles não poderiam participar de órgãos colegiados, devendo atuar apenas como Juízes-Assessores ${ }^{177}$. O que há em relação às Turmas Suplementares é verdadeira clonagem $^{178}$ indevida de Turmas.

Daí resulta o óbice às turmas suplementares, em que não há auxílio, nem sequer substituição. Os juízes são convocados para formar as turmas, compostas por um desembargador federal, que as presidem, e dois juízes de primeira instância ${ }^{179}$.

\subsubsection{Questão hierárquica e exemplo do TJDFT}

Surpreende o fato de que a formação das câmaras extraordinárias e turmas suplementares, conforme ressaltou o Ministro Nelson Jobim ${ }^{180}$, ocorre justamente por problemas de hierarquia, pois são os próprios tribunais (alguns deles) que se opõem à ampliação do número de seus membros:

\footnotetext{
${ }^{177}$ Expressão empregada pelo Ministro Marco Aurélio.

178 Termo cunhado pelo Ministro Marco Aurélio, explicado da seguinte forma: "Havia a convocação de juízes de primeira instância em número igual ao dos integrantes do Tribunal e, então, ocorria essa situação excepcionalíssima de uma mesma turma, em relação a determinados processos, atuar com a composição realmente prevista na Constituição Federal, na ordem jurídica, e, quanto a outros processos, atuar apenas com juízes convocados". Voto no RE $\mathrm{n}^{\circ}$ 597.133/RS, Relator Ministro Ricardo Lewandowski, Tribunal Pleno, julgado em 17.11.2010.

179 Conforme a PORTARIA/PRESI/CENAG 139 de 23 de março de 2011. http://processual.trf1.gov.br/Diversos/mutirao/arquivo/PortariaPresiCenag_139\%20altera_composicao_da S_turmas_suplementares_e_cronograma.pdf. Acesso em 18.6.2011.

${ }^{180}$ Em voto-vista nos autos do $\mathrm{HC} \mathrm{n}^{\circ}$ 81.347/SP, Relator Ministro Carlos Velloso, Segunda Turma, Julgamento iniciado em 8.10.2002 e findo em 1.4.2003.
} 
Por motivos estritamente vinculados ao problema hierárquico, alguns Tribunais se opõem ao aumento do número de seus Desembargadores.

Pelo caminho da convocação de Juízes Substitutos, os Tribunais continuam sem resolver o problema da sua composição numérica.

Solucionam o problema pela formação de Câmaras Extraordinárias com Juízes Substitutos.

Tenho receio não só pela conseqüência do caso concreto, mas, também, em relação ao problema administrativo.

Nessa linha, é louvável a iniciativa do Tribunal de Justiça do Distrito Federal e Territórios ao propor o Projeto de Lei $\mathrm{n}^{\circ}$ 4.567/08, para o aumento do número de desembargadores da Corte de 35 (trinta e cinco) para 40 (quarenta). O projeto foi aprovado, no final de 2010, pela Câmara dos Deputados e pelo Senado no dia 8.6.2011 $1^{181}$.

Diante da considerável elevação do número de processos distribuídos ao Tribunal (17.162 em 2003 e 29.258 em $2008^{182}$ ), é incontestável a necessidade do acréscimo, que ocorreu por meio de lei, como, aliás, deve ser sempre.

\subsection{Maioria de convocados nos órgãos colegiados dos Tribunais}

A jurisprudência do Supremo Tribunal Federal e do Superior Tribunal de Justiça vinha oscilando nos últimos anos no que se refere à eventual violação do princípio do juiz natural nos casos de composição de órgãos colegiados com maioria de juízes convocados.

Trata-se de tema melindroso. Conforme ementa do Habeas Corpus $\mathrm{n}^{\circ}$ $69.601 / \mathrm{SP}^{183}$ :

(...) o mecanismo das substituições dos juízes traduz dos aspectos mais delicados nas relações entre o Estado, no exercício da sua atividade persecutória, e o indivíduo, na sua condição de imputado nos processos penais condenatórios.

\footnotetext{
${ }^{181}$ Informação veiculada em:

http://www.senado.gov.br/noticias/Jornal/noticia.asp?codEditoria=4068\&dataEdicaoVer=20110609\&data EdicaoAtual $=20110609 \&$ nomeEditoria $=$ Administra\%C3\%A7\%C3\%A3o+P\%C3\%BAblica\&codNoticia $=$ 107221. Acesso em: 19.6.2011.

${ }^{182}$ Informação veiculada em: http://jusclip.com.br/camara-aprova-mais-cinco-desembargadores-para-otjdf/. Acesso em: 19.6.2001.

${ }^{183} \mathrm{HC} \mathrm{n}^{\circ}$ 69.601/SP, Relator Ministro Celso de Mello, Primeira Turma do Supremo Tribunal Federal, julgado em 24.11.1992 e publicado no DJ de 18.12.1992.
} 
Acerca do assunto, foram sintetizados os argumentos favoráveis e contrários à violação do juiz natural no Habeas Corpus $\mathrm{n}^{\circ} 72.941 / \mathrm{SP}^{184}$, julgado pela Sexta Turma do Superior Tribunal de Justiça:

(...) os argumentos contrários à tese da nulidade invocam a eventual incongruência que existiria em se admitir a legalidade do sistema de convocação, mas limitar a participação dos juízes substitutos. De acordo com este raciocínio, o juiz convocado equipara-se completamente ao desembargador, não podendo haver qualquer restrição relativa à composição da Câmara, ainda que numérica.

Os argumentos favoráveis à anulação baseiam-se no princípio do juiz natural, especialmente na intenção da Constituição Federal em reservar apenas aos Juizados Especiais o julgamento de recursos por turma composta por juízes de primeiro grau.

$\mathrm{O}$ argumento favorável à nulidade envolve um problema do ponto de vista prático: a impossibilidade de órgãos majoritariamente compostos por substitutos realizarem sessões de julgamentos, em prejuízo manifesto à razoável duração do processo.

Haveria, nesses casos, infringência ao princípio do juiz natural em virtude da mera composição do órgão por maioria de convocados?

A esse respeito, o Ministro Sepúlveda Pertence sustentou no Habeas Corpus $\mathrm{n}^{\circ} 84.414 / \mathrm{SP}^{185}$ :

(...) o Tribunal entendeu que, havendo lei estadual, criando cargos de juiz substituto de segundo grau, com hierarquia funcional equivalente à do Tribunal de Alçada, como ocorre no Estado de São Paulo, essa criação era legítima. E, se se entende legítima, não creio relevante que, no caso concreto, a maioria tenha sido de juízes substitutos convocados. Ou podem eles substituir os desembargadores, ou não podem.

(...)

O problema é este realmente: se é lícito ou não à lei estadual criar esse quadro de substitutos, os chamados "pingüins", da organização judiciária de São Paulo. Mas, se se admite a validade de sua criação, não vejo como restringir sua atuação a não serem relator ou a não comporem a maioria.

\footnotetext{
${ }^{184}$ HC 72.941/SP, Relatora Ministra Maria Thereza de Assis Moura, Sexta Turma do Superior Tribunal de Justiça, julgado em 11.9.2007 e publicado no DJe de 19.11.2007.

${ }^{185}$ HC 84.414, Relator Ministro Marco Aurélio, Primeira Turma do Supremo Tribunal Federal, julgado em 14.9.2004 e publicado no DJ de 26.11.2004.
} 
Ao concluir este estudo, verificou-se a insuficiência dos argumentos que sustentam ser a composição majoritária, por si só, capaz de violar o o juiz natural. Nesse sentido, decidiu-se no Habeas Corpus $\mathrm{n}^{\mathrm{o}} 110.227 / \mathrm{DF}^{186}$ :

HABEAS CORPUS. JULGAMENTO DE WRIT ORIGINÁRIO. TURMA COMPOSTA MAJORITARIAMENTE POR JUÍZES CONVOCADOS. VIOLAÇÃO AO PRINCÍPIO DO JUIZ NATURAL. INEXISTÊNCIA. CONVOCAÇÃO QUE ATENDE O DISPOSTO NA LOMAN E NA LEI DE ORGANIZAÇÃO JUDICIÁRIA E SE PRESTA APENAS A SUBSTITUIÇÃO EVENTUAL. PRONÚNCIA. CONFIRMAÇÃO PELO TRIBUNAL EM SEDE DE RSE. INAUGURAÇÃO DA SEGUNDA FASE DO PROCEDIMENTO DO JÚRI. PENDÊNCIA DE RECURSOS DE ÍNDOLE EXCEPCIONAL. POSSIBILIDADE.

1. Não há falar em violação ao princípio do juiz natural nos casos em que, embora o julgamento tenha contado majoritariamente com juízes convocados, o sistema de convocação encontre amparo na legislação.

2. No caso, a convocação encontra previsão na Lei de Organização Judiciária do Distrito Federal, e se presta exclusivamente a suprir ausências decorrentes de férias, afastamentos ou impedimentos eventuais dos Desembargadores titulares.

Entende-se que ou bem a convocação é regular e, assim, não haveria nenhum obstáculo à maioria de convocados no órgão; ou a convocação infringe o sistema legal de substituições e, por conseguinte, o número crescente de convocados teria o condão apenas de agravar a violação, devido à quantia superior de desvios na forma de compor o órgão.

Pelo quanto pesquisado, não há nenhum preceito da garantia do juiz natural que constitua empecilho à composição majoritária de convocados. A única possível consequência de tal composição é se afastar da jurisprudência do tribunal, o que não significa transgredir o princípio do juiz natural.

Conforme asseverou o Ministro Ayres Britto:

Quando a Turma julgadora é composta, na sua maioria, por convocados, há um risco de se fugir da tendência do Tribunal. Daí a dizer que o princípio constitucional do juiz natural restou vulnerado, parece-me que vai uma distância ${ }^{187}$.

\footnotetext{
${ }^{186}$ Relator Ministro Og Fernandes, Sexta Turma do Superior Tribunal de Justiça, julgado em 4.8.2009 e publicado no DJe em 7.12.2009.

${ }^{87} \mathrm{HC} \mathrm{n}^{\circ}$ 84.414/SP, Relator Ministro Marco Aurélio, Primeira Turma do Supremo Tribunal Federal, julgado em 14.9.2004 e publicado no DJ de 26.11.2004.
} 
Argumenta-se, com fundamento no artigo 98, inciso I, da Lei Maior ${ }^{188}$

que:

\begin{abstract}
A intenção do constituinte de 1988 foi, claramente, a de permitir que os juízes de primeira instância possam julgar casos de menor complexidade, compondo, sozinhos, uma turma de julgamento de recursos. Tal raciocínio conduz à conclusão, contrario sensu, de que os casos de maior complexidade devem ser julgados por Turmas compostas por juízes de segunda instância ${ }^{189}$.
\end{abstract}

Nada a reparar em relação ao citado raciocínio, que é perfeitamente apropriado para sustentar a inconstitucionalidade das câmaras extraordinárias e turmas suplementares, nas hipóteses em que há formação integral do órgão com convocados. Entende-se, no entanto, não ser o argumento plausível para sustentar a irregularidade da formação de órgãos colegiados majoritariamente com juízes convocados.

Ao que parece, em alguns casos nos quais se decidiu pela ilegalidade das câmaras extraordinárias ou turmas suplementares, aduziu-se, desarrazoadamente, que a maioria de juízes convocados nos órgãos seria um argumento complementar para a declaração da nulidade dos acórdãos por eles proferidos.

Concluiu-se, ao longo deste trabalho, que a maioria de magistrados convocados, por si só, não viola o princípio do juiz natural. Aliás, serão excepcionais os casos em que isso ocorrerá quando as convocações para substituir forem, de fato, legítimas ${ }^{190}$. Nessas ocasiões o princípio-garantia do juiz natural não é transgredido e deve-se atribuir idêntico valor aos votos dos magistrados efetivos e convocados.

\footnotetext{
${ }^{188}$ Art. 98. A União, no Distrito Federal e nos Territórios, e os Estados criarão:

I - juizados especiais, providos por juízes togados, ou togados e leigos, competentes para a conciliação, o julgamento e a execução de causas cíveis de menor complexidade e infrações penais de menor potencial ofensivo, mediante os procedimentos oral e sumaríssimo, permitidos, nas hipóteses previstas em lei, a transação e o julgamento de recursos por turmas de juízes de primeiro grau;

${ }^{189}$ HC 72.941/SP, Voto da Relatora Ministra Maria Thereza de Assis Moura, Sexta Turma do Superior Tribunal de Justiça, julgado em 11.9.2007 e publicado no DJe de 19.11.2007.

${ }^{190}$ Exemplo recente ocorreu na Sexta Turma do Superior Tribunal de Justiça. Durante período de licença médica da Ministra Maria Thereza de Assis Moura, a Turma ficou temporariamente composta pelo Ministro Og Fernandes e pelos Desembargadores Convocados Vasco Della Giustina e Francisco Haroldo Rodrigues de Albuquerque.
} 


\section{Conclusões}

1. O rigor científico exige, em específico na seara jurídica, clareza conceitual. A precisão terminológica é imprescindível para a comunicação eficaz entre o intérprete e seus destinatários.

2. O princípio é um gênero da família norma jurídica que comporta vários níveis de concretização. Em uma sociedade democrática, os princípios colidem amiúde, indicando soluções diversas para um mesmo problema. Nessas situações, admitem ponderação de acordo com o peso de cada um deles no caso concreto. Cabe ao intérprete, ao aplicá-los, fazer um juízo de avaliação, de modo a resguardar, por meio de concessões recíprocas, o máximo de cada um dos princípios em questão, na medida do possível.

3. Há princípios jurídicos que objetivam assegurar garantias aos cidadãos. Essa espécie do gênero princípio pode ser definida, de acordo com a tipologia de Canotilho, como princípio-garantia. O juiz natural e a razoável duração do processo constituem exemplos dessa espécie.

4. O princípio-garantia do juiz natural tem sua origem na Carta Magna inglesa de 1215. Posteriormente, foi introduzido no Direito norte-americano e francês. Atualmente, é previsto não só em diversas Constituições democráticas, como também em inúmeros textos internacionais.

5. O juiz natural encontrou abrigo no ordenamento pátrio desde a Constituição do Império de 1824. No Brasil, significa, hodiernamente, a proibição aos institutos da comissão e evocação. Isso quer dizer que são vedados os tribunais extraordinários e a derrogação de competência. Esse princípio não se opõe, aqui, aos juízos especiais (atribuição), nem tampouco ao foro privilegiado por prerrogativa de função.

6. O princípio do juiz natural, assim como outros a ele relacionados (devido processo legal, legalidade e imparcialidade), é intrínseco ao Estado Democrático de Direito. Esses princípios, que se complementam, constituem garantias aos cidadãos de respeito das regras do jogo pelo Poder Judiciário, em especial, no exercício da jurisdição. 
7. A ligação entre o devido processo legal e o juiz natural é estreita e intensa de tal forma, que este constitui corolário lógico daquele. O primeiro, ao ser previsto na Constituição de 1988, robusteceu diversas garantias processuais, dentre elas a do juiz natural.

8. O princípio do juiz natural e o da imparcialidade do juiz são interdependentes. Além disso, os atributos da imparcialidade e da independência são inerentes à naturalidade do juiz.

9. A legalidade também é inseparável do juiz natural, visto que um dos planos deste princípio-garantia é o da fonte, segundo o qual a ordem taxativa de competência de um ordenamento jurídico deve ser estabelecida em lei e não em qualquer outra espécie normativa de inferior hierarquia.

10. A razoável duração do processo, embora não tenha sido prevista na redação original da Carta Política de 1988, já integrava o sistema constitucional brasileiro, visto que, além de ser decorrência do devido processo legal, foi consagrada em tratados internacionais dos quais a República Federativa do Brasil é parte.

11. Os princípios da razoável duração do processo e do juiz natural indicam soluções opostas, nas hipóteses em que se alegue violação deste, em virtude da convocação de magistrados para atuar em tribunal. Assim, devem ser apreciados de acordo com seu peso no caso concreto. Nessa ponderação é indesejável suprimir garantias processuais dos cidadãos com o desiderato de tornar mais célere a prestação jurisdicional. Isso porque a aceleração desta, que tenha por consequência a diminuição de garantias processuais, conduz a uma justiça pronta, mas censurável.

12. O Supremo Tribunal Federal e o Superior Tribunal de Justiça já julgaram diversos casos em que se alegava violação ao princípio do juiz natural em decorrência da formação de órgãos colegiados de tribunais com juízes convocados. É possível dividi-los em três situações essencialmente distintas: (i) juízes convocados nos Estados em que havia tribunal de alçada; (ii) câmaras extraordinárias e turmas suplementares; e (iii) maioria de magistrados convocados nos órgãos colegiados dos Tribunais.

13. O acesso temporário de juízes aos tribunais, por meio da convocação, só deve ser permitido aos magistrados que, no escalonamento hierárquico da carreira, já estejam aptos a exercer definitivamente o cargo. A ideia fundamental é a 
de que o juiz, para ser promovido a desembargador, deve já ter exercido os cargos anteriores da carreira e idealmente adquirido experiência e maturidade para tal. Desse modo, as designações de juízes para substituir membros de tribunal devem obedecer rigorosamente à ordem decrescente de antiguidade deles. Assim, serão atendidos os preceitos de transparência e previsibilidade.

14. Como o acesso definitivo aos tribunais de justiça dos Estados em que havia tribunal de alçada deveria ocorrer, em tese, dentre os membros dos tribunais de alçada (de acordo com a redação original do artigo 93, III, da Lei Maior), as convocações também deveriam recair sobre eles, obedecendo-se ao disposto no artigo $118, \S 1^{\circ}$, III.

15. As câmaras extraordinárias foram criadas com o objetivo específico (ad hoc) de diminuir a quantidade de processos pendentes de julgamento no Tribunal bandeirante. Essas câmaras eram compostas, em regra, por três magistrados convocados e presididas por desembargador sem voto. Embora se reconheça o elogiável objetivo de promover a razoável duração do processo, a forma pela qual as convocações eram feitas violava a garantia do juiz natural. De acordo com esse princípio, a competência dos órgãos jurisdicionais deve ser estabelecida em lei. No Estado de São Paulo, a Lei Complementar no $646 / 90$ previu a criação de um quadro permanente de juízes de direito substitutos em segundo grau para substituir ou auxiliar desembargadores mediante designação do presidente do tribunal. No entanto, as convocações, no referido tribunal, não objetivavam a substituição, nem sequer o auxílio de desembargadores, tinham a finalidade exclusiva de formar câmaras extraordinárias. Além disso, elas eram supridas por juízes de primeira instância, em regime de voluntariado, o que infringia o disposto na própria lei complementar estadual e nos artigos 107 e 118 da LOMAN.

16. O artigo 107 da LOMAN veda a convocação de juiz para exercer cargo ou função nos tribunais, à exceção da substituição ocasional de seus integrantes. Esta é permitida apenas quando houver vaga ou afastamento de membro de tribunal por prazo superior a 30 (trinta) dias, conforme o artigo 118 desta lei. Portanto, o auxílio contraria o estabelecido na LOMAN.

17. Na mesma linha das câmaras extraordinárias em São Paulo, foram criadas turmas suplementares pelo Tribunal Regional Federal da Primeira Região com o escopo de reduzir a quantidade de processos represados no tribunal. $\mathrm{O}$ artigo $4^{\circ}$ da Lei 
12.011/09 prevê a convocação de juízes federais para auxiliar em segundo grau, em caráter excepcional e quando o acúmulo de serviço exigir. Esse dispositivo contraria o previsto no artigo 107 da LOMAN. Há, aqui, o conflito entre dispositivos de lei complementar e lei ordinária. Com base no artigo 93, caput, da Constituição Federal, entende-se competir à lei complementar reger o sistema das convocações nos tribunais. Assim, verifica-se que o citado artigo $4^{\circ}$, ao prever a figura do auxílio, extrapola o âmbito de competência de lei ordinária, sendo, portanto, inconstitucional. Além disso, as convocações, do modo como são realizadas para atuação nas turmas suplementares, não têm o intuito de auxílio, nem sequer de substituição. Ao contrário, têm o objetivo único de constituir novas câmaras, para agilizar o julgamento de processos do tribunal.

18. A maioria de juízes convocados em órgãos colegiados, por si só, é insuficiente para violar o princípio do juiz natural. Sendo regulares as designações dos magistrados para substituir em segundo grau, a única consequência dessa maioria é o possibilidade de se fugir da jurisprudência do tribunal. Isso, contudo, não transgride a garantia do juiz natural. 


\section{Referências bibliográficas}

ALENCAR, Laura Cunha de. O princípio do juiz natural e a legitimidade dos julgamentos realizados por colegiados formados por juízes convocados. Revista dos Estudantes de Direito da Universidade de Brasília, nº 8, p. 346-367, 2009.

ARAÚJO CINTRA, Antônio Carlos de; GRINOVER, Ada Pellegrini; DINAMARCO, Cândido Rangel. Teoria geral do processo. 23ª edição. Malheiros Editores, 2007.

ÁVILA, Humberto Bergmann. Teoria dos princípios: da definição à aplicação dos princípios jurídicos. 12 ${ }^{\mathrm{a}}$ Edição. São Paulo: Malheiros Editores, 2011.

BARBOSA, Rui. Oração aos moços. Rio de Janeiro: Edições Casa de Rui Barbosa, 1999. Versão eletrônica disponível em: http://www.casaruibarbosa.gov.br/dados/DOC/ artigos /rui_barbosa/FCRB_RuiBarbosa_Oracao_aos_mocos.pdf. Acesso em: 3.6.2011.

BARROSO, Luís Roberto. Interpretação e aplicação da constituição: fundamentos de uma dogmática constitucional transformadora, $7^{\text {a }}$ Edição. São Paulo: Editora Saraiva, 2009.

BEDÊ JÚNIOR, Américo; SENNA, Gustavo. Princípios do processo penal: entre o garantismo e a efetividade. São Paulo: Revista dos Tribunais, 2009.

CALMON ALVES, Eliana. Princípios e garantias constitucionais do processo. Artigo eletrônico disponível em: http://bdjur.stj.jus.br/xmlui/handle/2011/295. Acesso em: 20.4.2011.

CANOTILHO, José Joaquim Gomes. Direito constitucional. $5^{\text {a }}$ edição. Coimbra: Livraria Almedina, 1991.

CARNEIRO, Athos Gusmão. O litisconsórcio facultativo ativo ulterior e os princípios do juiz natural e do devido processo legal in Revista Síntese de Direito Civil e Processual Civil, v. 1, nº 1 , setembro/outubro de 1999.

CARVAlHO, Luis Gustavo Grandinetti Castanho de. Processo penal e constituição: princípios constitucionais do processo penal. 5a Edição. Editora Lumen Juris, 2009.

CIRILO DE VARGAS, José. Processo penal e direitos fundamentais. Belo Horizonte: Del Rey Editora, 1992.

CONEGLIAN, Olivar Augusto Roberti. Princípio do juiz natural in Princípios processuais civis na Constituição. Organização: OLIVEIRA NETO, Olavo de; CASTRO LOPES, Maria Elizabeth de. Rio de Janeiro: Elsevier, 2008.

COUTINHO, Jacinto Nelson de Miranda. O princípio do juiz natural na CF/88: ordem e desordem. Artigo eletrônico disponível em: http://www2.senado.gov.br/ bdsf/item/id/176542. Acesso em 20.4.2011.

CRETELLA NETO, José. Fundamentos principiológicos do processo civil. $2^{\text {a }}$ Edição. Rio de Janeiro: Editora Forense, 2006. 
DIAS, Jorge de Figueiredo. Direito processual penal. $1^{a}$ Edição. Coimbra: Coimbra Editora, 1974.

ECO, Humberto. Como se faz uma tese. Tradução de Gilson Cesar Cardoso de Souza. $22^{\mathrm{a}}$ edição. São Paulo: Perspectiva, 2009.

FERNANDES, Antonio Scarance. Processo penal constitucional. 6a Edição. São Paulo: Revista dos Tribunais, 2010.

GOMES, Luiz Flavio. Apontamentos sobre o princípio do juiz natural in Revista dos Tribunais, São Paulo, v. 83, nº 703, maio de 1994.

GRINOVER, Ada Pellegrini. O princípio do juiz natural e sua dupla garantia. in $\mathbf{O}$ processo em sua unidade - II. Coordenação: GRINOVER, Ada Pelegrini. Rio de Janeiro: Forense, 1984.

NERY JÚNIOR, Nelson. Princípios do processo civil na Constituição Federal. São Paulo: Editora Revista dos Tribunais, 1992.

LAVACA, Thaís Aroca Datcho Lacava. A garantia da razoável duração da persecução penal. Dissertação de Mestrado. Universidade de São Paulo. São Paulo: 2009.

LONGO, Luís Antônio. A garantia do juiz natural e a nova redação do art. 253 do código de processo civil in As garantias do cidadão no processo civil - relações entre constituição e processo. Organização: PORTO, Sérgio Gilberto. Porto Alegre, Livraria do Advogado, 2003.

MARQUES, José Frederico. Juiz natural in Enciclopédia Saraiva do Direito, vol. 46. São Paulo: Saraiva, 1977.

MENDES, Gilmar Ferreira; COELHO, Inocêncio Mártires; GONET BRANCO, Paulo Gustavo. Curso de direito constitucional. São Paulo: Saraiva, 2007.

MENDES, Ítalo Fioravanti Sabo. O duplo grau de jurisdição no processo civil: um exame à luz da constituição e da instrumentalidade do processo. Tese de Doutorado. Universidade de Brasília. Brasília: 2008.

MOURA, Maria Thereza Rocha de Assis. Julgamentos de recursos proferidos por turma composta majoritariamente por juízes de primeiro grau in Análise de precedentes criminais do Superior Tribunal de Justiça. Organização: RESENDE, Sérgio Antônio de; PINTO, Felipe Martins; MOURA ESTEVES, Heloísa Monteiro de. Belo Horizonte: Atualizar, 2009.

NUCCI, Guilherme de Souza. Princípios constitucionais penais e processuais penais. São Paulo: Revista dos Tribunais, 2010.

OLIVEIRA, Eugênio Pacelli de. Curso de processo penal. $11^{\text {a }}$ Edição. Rio de Janeiro: Editora Lumen Juris, 2009. 
PEIXINHO, Manoel Messias. A interpretação da constituição e os princípios fundamentais. $3^{\text {a }}$ Edição. Rio de Janeiro: Editora Lumen Juris, 2003.

PETRY DA SILVA, Marla Sibeli. Juízes convocados e princípio do juiz natural. Artigo eletrônico disponível em: http://bdjur.stj.gov.br/xmlui/handle/2011/20618. Acesso em 18.4.2011.

PORTANOVA, Rui. Princípios do processo civil. $4^{\text {a }}$ Edição. Porto Alegre: Livraria do Advogado, 2001.

RANGEL, Paulo. Direito processual penal, $18^{\mathrm{a}}$ Edição. Rio de Janeiro: Lumen Juris, 2009.

ROSAS, Roberto. Direito processual constitucional. $3^{\text {a }}$ Edição. São Paulo: Revista dos Tribunais, 1999.

SCHWAB, Karl Heinz. Divisão de funções e o juiz natural in Justitia, v. 49, $\mathrm{n}^{\circ}$ 139, julho/setembro de 1987.

SILVA, Carlos Augusto. O princípio do juiz natural in Genesis Revista de Direito Processual Civil. Curitiba, n. 28, abril/julho de 2003.

SPAGNOLO, Juliano. A garantia do juiz natural e a nova redação do art. 253 do código de processo civil in As garantias do cidadão no processo civil - relações entre constituição e processo. Organização: PORTO, Sérgio Gilberto. Porto Alegre, Livraria do Advogado, 2003.

TAORMINA. Giudice naturale e processo penale. Roma: Bulzoni Editore, 1972.

TOURINHO FILHO, Fernando da Costa. Manual de direito processual penal. $11^{\mathrm{a}}$ Edição. São Paulo: Editora Saraiva, 2009.

TUCCI, Rogério Lauria. Juiz natural, competência recursal, preclusão pro iudicato, violação de literal disposição de lei e ação rescisória in Revista dos tribunais. São Paulo, v. 94, nº 838, agosto de 2005.

Determinação de juiz natural em tribunal in Revista dos Tribunais, São Paulo, v. 95, nº 854, dezembro de 2006.

Princípio e regras orientadoras do novo processo penal brasileiro. Rio de Janeiro: Forense, 1986.

VARGAS, José Cirilo de. Processo penal e direitos fundamentais. Belo Horizonte: Del Rey Editora, 1992.

YOSHIKAWA, Eduardo Henrique de Oliveira. O julgamento de recursos por juízes de primeira instância e o art. 107 da LOMAN: nulidade absoluta por ofensa ao princípio do juiz natural in Revista Dialética do Direito Processual. São Paulo, n. 63, jun. 2008. 
Origem e evolução do devido processo legal substantivo: o controle da razoabilidade das leis do século XVII ao XXI. São Paulo: Letras Jurídicas, 2007. 